\title{
EFEITO DO USO DE SUCEDÂNEO E DO PROCESSAMENTO DO MILHO NO DESEMPENHO DE BEZERROS (AS) DA RAÇA HOLANDESA EM ALEITAMENTO E APÓS A DESMAMA
}

\section{ADRIANA REGINA BAGALDO}

ZOOTECNISTA

Orientador: Prof. Dr. Alexandre Vaz Pires

Dissertação apresentada à Escola Superior de Agricultura "Luiz de Queiroz", Universidade de São Paulo, para obtenção do título de Mestre em Agronomia, Área de Concentração: Ciência Animal e Pastagens. 


\section{ERRATA}

\begin{tabular}{|c|c|c|c|}
\hline Página & Local & Escrito & Considerar como \\
\hline 41 & $12^{\mathrm{a}}$ linha & (Tabela 3) & (Tabela 5) \\
\hline 40 & Tabela, 5alinha, 2a coluna & 0,63 & 0,83 \\
\hline $40,49,56$ & Tabela, 2alinha, 12 ${ }^{\mathrm{a}}$ e $14^{\mathrm{a}}$ coluna & MxF & M vs. F \\
\hline
\end{tabular}


Dados Internacionais de Catalogação na Publicação (CIP)

DIVISÃO DE BIBLIOTECA E DOCUMENTAÇĀO - Campus "LuIZ de OUEIrOZ"/USP

Bagaido, Adriana Regina

Efeito do uso de sucedâneo e do processamento do milho no desempenho de Bezerros (as) da raça Holandesa em aleitamento e após a desmama / Adriana Regina Bagaldo. - - Piracicaba, 2000.

76 p. : ill.

Dissertação (mestrado) - - Escola Superior de Agricultura Luiz de Queiroz, 2000. Bibliografia.

1. Aleitamento 2. Amido de milho 3. Bezerro Holandês 4. Desmama 5. Desempenho animal 6. Floculação 7. Processamento agricola 8. Sucedâneo de leite 1. Título

CDD 636.214

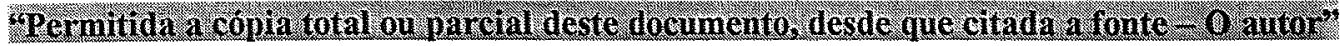


Aos meus queridos pais,

Lázaro e Regina, pelo amor, incentivo e compreensão da minha ausência desde o início da minha formação,

Ao meu irmão,

Carlos pela eterna amizade e cumplicidade,

A minha avó,

Lúcia, pelo carinho e dedicação de todos esses anos,

DEDICO. 


\section{AGRADECIMENTOS}

À Escola Superior de Agricultura "Luiz de Queiroz" - USP e ao Departamento de Produção Animal, pela oportunidade de realização deste curso.

À Fundação de Apoio a Pesquisa do Estado de São Paulo (FAPESP), pela concessão da bolsa de estudo.

À Sul Mineira Alimentos e Prolac, pelo fornecimento dos concentrados e do sucedâneo.

À Fazenda Pinhalzinho em especial ao Sr. Arnaldo Lima, por permitir a realização deste trabalho através do empréstimos dos bezerros e pela estadia.

Ao Prof. Dr. Alexandre Vaz Pires, pela valiosa orientação e importantes ensinamentos e também por acreditar em mim.

Ao Prof. Dr. José Manual Correa de Simas, pelas sugestões e colaboração na interpretação dos dados.

À Profa. Dra. Ivanete Susin pela amizade e disposição em me ajudar na elaboração desta dissertação.

Ao Prof. Dr. Flávio Augusto Portela Santos pelas sugestões durante a fase final desta dissertação.

Ao Prof. Dr. Wilson Matos, pela simpatia e amizade durante esses dois anos de convivência.

À Paula, pela amizade, cumplicidade e pela ajuda dos momentos mais difíceis durante a realização deste trabalho.

Ao amigo Paulo Henrique Mazza pela amizade e pelos conselhos na realização deste trabalho.

Ao Heyder, pela ajuda com a análise estatística.

Aos meus amigos da Fazenda Pinhalzinho: Stela, Ana, Roque, Jair, Chico, Sr. Antônio, Sr. Anísio, Maurício e a todos que lá conheci, pela amizade e valiosa ajuda nos momentos que mais precisava. 
Á amiga e secretária Cleide Martins do Depto. de Produção Animal pela amizade e simpatia com que sempre me tratou.

Aos funcionários do Laboratório de Bromatologia e Nutrição animal do Departamento de Produção Animal, Carlos César Alves, Fabiana e Karen, pelo auxilio e amizade durante a minha passagem por lá.

À Neusa e Waldir, pelo carinho, respeito durante as minhas horas de estudo e principalmente por me tratarem como uma verdadeira filha.

À minha amiga especial, Renice, pelo apoio e compreensão da minha ausência em momentos que mais precisava.

MUITO OBRIGADA! 


\section{SUMÁRIO}

Página

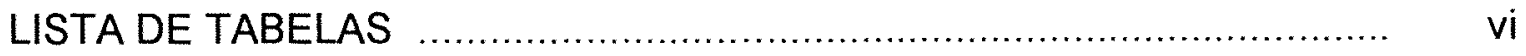

LISTA DE FIGURAS ................................................................. viii

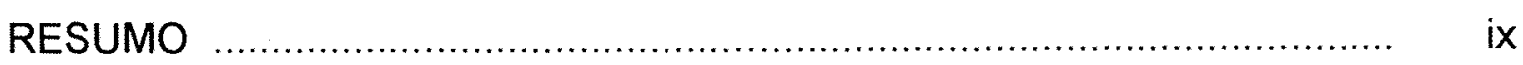

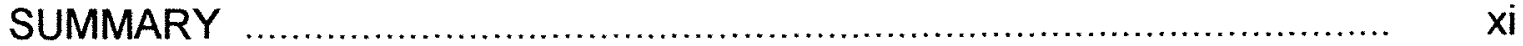

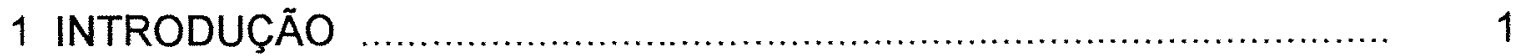

2 REVISÃO DE LITERATURA …................................................ 3

2.1 Características físicas e químicas do amido .................................... 3

2.2 Processamento de grãos …...................................................... 4

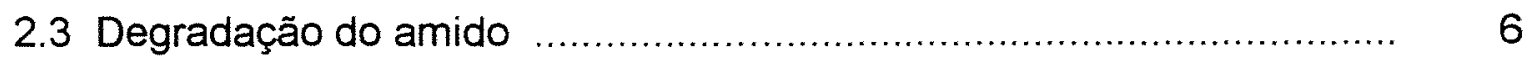

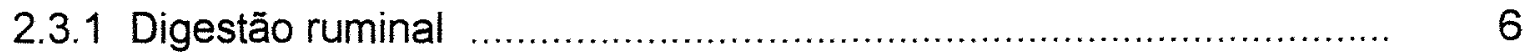

2.3.2 Digestão no intestino delgado ................................................. 9

2.3.3 Digestão no intestino grosso ....................................................... 11

2.4 Efeito da densidade do grão floculado .......................................... 11

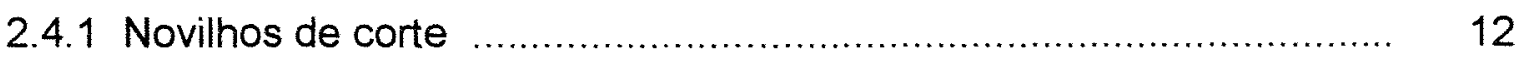

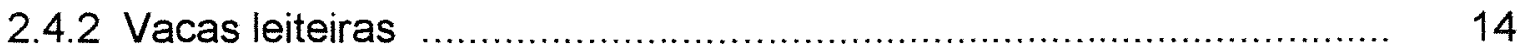

2.5 Processamento de grãos na dieta de bezerros …........................... 16

2.5.1 Desenvolvimento do rúmen ........................................................ 16

2.5.2 Forma física da ração inicial ....................................................... 17

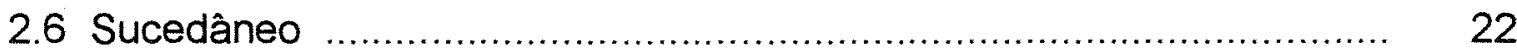

2.6.1 Digestão no abomaso ................................................................. 23

2.6.2 Digestão no intestino delgado .............................................. 24

2.6.3 Digestibilidade da dieta líquida e desempenho dos bezerros ......... 25

3 MATERIAL E MÉTODOS ........................................................ 28

3.1 Animais e instalações experimentais .......................................... 28

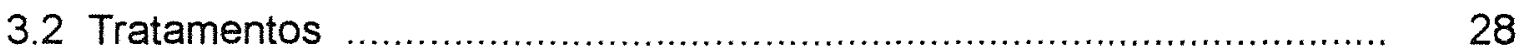


3.3 Alimentação e manejo dos animais …............................................ 31

3.4 Colheita de dados e de amostras ............................................... 32

3.5 Processamento do grão de milho ….............................................. 33

3.6 Análises bromatológicas .......................................................... 33

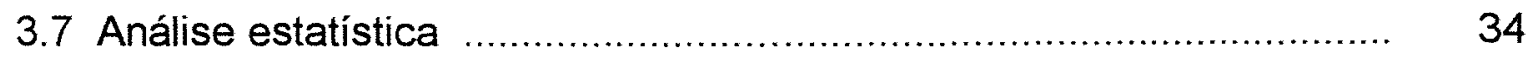

4 RESULTADOS E DISCUSSÕES ................................................. 36

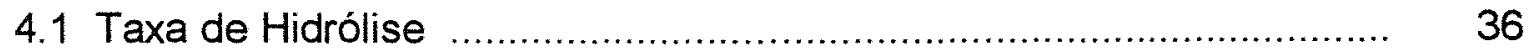

4.2 Desempenho dos 15 dias à desmama .......................................... 37

4.2.1 Consumo diário de concentrado ................................................. 37

4.2.2 Consumo diário de matéria seca total (MS) …............................. 41

4.2.3 Ganho de peso ..................................................................... 41

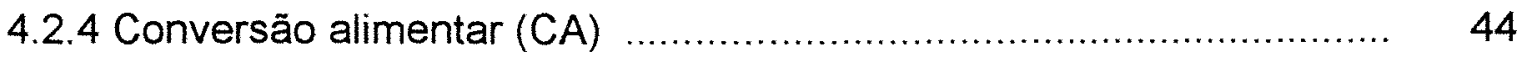

4.2.5 Peso vivo à desmama ............................................................ 45

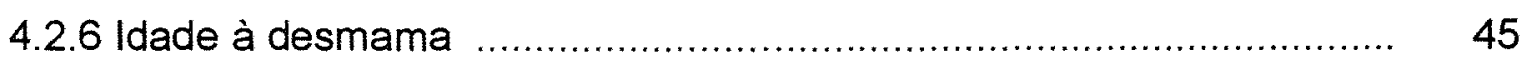

4.3 Desempenho da desmama ao final do experimento (120 dias) ......... 46

4.3.1 Consumo de matéria seca total (MS) ......................................... 46

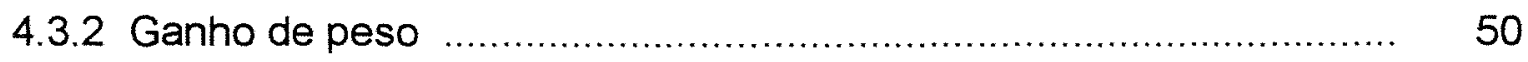

4.3.3 Conversão alimentar (CA) …............................................ 51

4.3.4 Idade ao início do consumo de silagem de milho ......................... 51

4.4 Desempenho dos 15 dias de idade ao final do experimento (120 dias) 52

4.4.1 Consumo de matéria seca total ................................................. 52

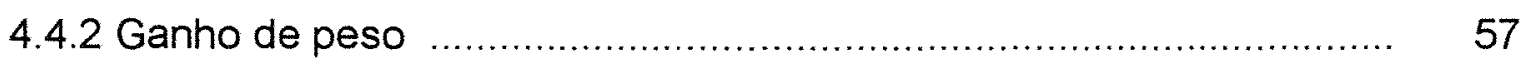

4.4.3 Conversão alimentar ................................................................. 59

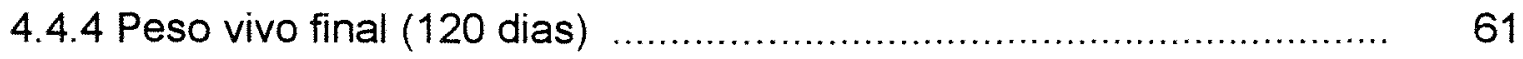

4.5 Taxa de mortalidade e ocorrência de diarréia ................................... 61

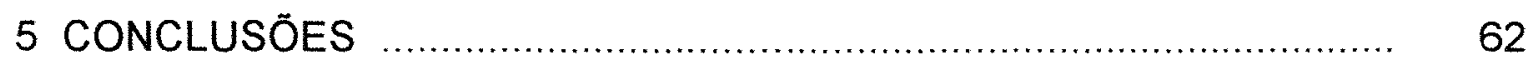

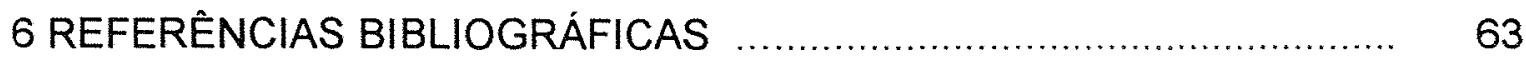




\section{LISTA DE TABELAS}

Página

TABELA 1. Composição do concentrado contendo milho floculado ....... 29

TABELA 2. Análise mineral dos concentrados, sucedâneo e silagem de milho

TABELA 3. Composição dos alimentos em porcentagem da MS

TABELA 4. Esquema da análise de variância

TABELA 5. Efeitos do processamento do milho e tipo de dieta líquida sobre o desempenho dos(as) bezerros(as) na prédesmama (dados corrigido pela covariável peso aos 15 dias).

TABELA 6. Interação entre processamento do milho e tipo de dieta líquida sobre o desempenho dos(as) bezerros(as) na prédesmama (dados corrigido pela covariável peso aos 15 dias).

TABELA 7. Efeitos do processamento do milho e tipo de dieta líquida sobre o desempenho dos(as) bezerros(as) após a desmama (dados corrigido pela covariável peso aos 15 dias)

TABELA 8. Interação entre processamento do milho e tipo de dieta líquida sobre o desempenho dos(as) bezerros(as) após a desmama (dados corrigido pela covariável peso aos 15 dias)

TABELA 9. Efeitos do processamento do milho e tipo de dieta líquida sobre o desempenho dos(as) bezerros(as) dos 15 aos 120 dias de idade (dados corrigido pela covariável peso aos 15 dias). 
TABELA 10. Interação entre processamento do milho e tipo de dieta líquida sobre o desempenho dos(as) bezerros(as) na dos 15 aos 120 dias de idade (dados corrigido pela covariável peso aos 15 dias) 


\section{LISTA DE FIGURAS}

Página

FIGURA 1. Taxa de hidrólise in vitro do amido dos concentrados 37

FIGURA 2. Consumo de matéria seca dos 15 dias ao final do experimento

FIGURA 3. Ganho de peso médio diário dos 15 dias ao final do experimento 59

FIGURA 4. Conversão alimentar dos 15 dias ao final do experimento .... 60 


\title{
EFEITO DO USO DE SUCEDÂNEO E DO PROCESSAMENTO DO MILHO NO DESEMPENHO DE BEZERROS(AS) DA RAÇA HOLANDESA EM \\ ALEITAMENTO E APÓS A DESMAMA
}

\author{
Autora: ADRIANA REGINA BAGALDO \\ Orientador: Prof. Dr. ALEXANDRE VAZ PIRES
}

\section{RESUMO}

Noventa e seis bezerros (as) da raça Holandesa foram utilizados para avaliar a substituição do leite integral pelo sucedâneo e os efeitos do processamento do milho em dietas iniciais. Os animais foram distribuidos num delineamento experimental de blocos ao acaso em função do sexo e data de nascimento, em um arranjo fatorial $2 \times 4$, correspondendo ao tipo de dieta líquida (leite integral ou sucedâneo) e ao processamento de milho (milho moído fino, milho floculado a $283 \mathrm{~g} / \mathrm{L}$, milho floculado a $360 \mathrm{~g} / \mathrm{L}$ e milho floculado a $437 \mathrm{~g} / \mathrm{L}$ ). O período experimental foi dos 15 aos 120 dias de vida, sendo o peso aos 15 dias utilizado como covariável. Os animais receberam 4 litros da dieta líquida divididos em dois horários. Água e concentrado foram fornecidos ad libitum desde os primeiros dias de vida, sendo este fornecido em pequenas quantidades de acordo com o consumo. Quando o consumo de concentrado atingia $800 \mathrm{~g} / \mathrm{dia}$, durante três dias consecutivos, os animais eram desmamados bruscamente e pesados. A partir da desmama, o concentrado continuava a ser fornecido em quantidades crescentes até atingir $2,5 \mathrm{~kg} / \mathrm{dia}$, onde esse valor era fixado e silagem de milho era fornecida ad libitum. O peso dos animais era registrado aos 15 dias, semanalmente, na desmama e ao final do experimento, enquanto que o fornecimento de concentrado e silagem de milho foi registrada 
diariamente. A substituição do leite integral pelo sucedâneo teve efeito prejudicial no desempenho dos(as) bezerros(as) durante a fase de prédesmama, entretanto o consumo de concentrado e a idade a desmama foram semelhantes. Durante o período pós-desmama o consumo de matéria seca e o ganho de peso foram afetados pela substituição do leite pelo sucedâneo $(\mathrm{P}<0,05)$, e a idade ao início do consumo de silagem foi maior para os animais tratados com sucedâneo, entretanto não houve diferença na conversão alimenta. Ao analisar os dados durante toda a fase experimental, verificou-se que o consumo de matéria seca, o ganho de peso diário, a conversão alimentar e o peso vivo aos 120 dias de vida foram prejudicados pelo sucedâneo. Os (as) bezerros (as) demonstraram desempenho semelhante para o fornecimento da dieta contendo milho moído fino e os floculados em todas as fases estudadas, entretanto os animais que receberam o sucedâneo e o milho moído fino apresentaram o menor ganho de peso em conseqüência ao menor consumo de matéria seca dos 15 aos 120 dias de vida. 


\title{
EFFECTS OF MUK REPLACER AND PROCESSED CORN ON HOLSTEIN CALVES PERFORMANCE PRE AND POSTWEANING
}

\author{
Author: ADRIANA REGINA BAGALDO \\ Adviser: Prof. Dr. ALEXANDRE VAZ PIRES
}

\section{SUMMARY}

Ninety six Holstein calves aged 15 days were used to evaluate the effects of the substitution of whole milk by a milk replacer, and the effects of processed corn in starters. The animals were blocked by sex and bith date to a $2 \times 4$ factorial arrangement of treatments. The factors were: 1-whole milk and milk replacer, and 2-fined ground corn, steam flaked corn $283 \mathrm{~g} / \mathrm{L}$, steam flaked corn $360 \mathrm{~g} / \mathrm{L}$ and steam flaked corn $437 \mathrm{~g} / \mathrm{L}$. The animals remained on trial until 120 days of age, and the 15 day weight was used as covariate. The animals were fed 2 liters of the liquid diet twice daily. Water and starters were offered ad libitum since the first day of life. When the starter intake reached $800 \mathrm{~g}$ for three consecutives days, the animals were weaned and weighed. After weaning, when the starter intake reached $2,5 \mathrm{~kg}$, these value was then fixed and corn silagen was offered ad libitum. Calves and starter orts were weighed weekly while the corn silage offered and the orts were weighed daily. The substitution of whole milk by the milk replacer had a harmful effect on calves performance during pre weaning, but the starter intake and the weaning age were similars. During postweaning, the dry matter intake and the average daily body gain had a negative effect by the substituion of the whole milk by the milk replacer,. From 15 to 120 days of age, the dry matter intake, daily body gain, feed conversion and body 
weight at 120 days had a harmful effect because of the milk replacer. The calves had similar performance for the starters containing fined ground corn and steam flaked corn on different densities, however, those animals which were fed milk replacer and fined groun floor had the lower daily body gain due to the lower dry matter intake. 


\section{INTRODUÇĀO}

O amido é o maior componente energético dos grãos de cereais (55 a $77 \%$ ) e é uma importante fonte de energia para bezerros desmamados, assim a otimização em seu emprego. As fontes mais comuns de amido em rações são os grãos de milho e sorgo. A melhoria na utilização do amido é dependente dos métodos de processamento, espécie animal e a fonte do amido (grão) (Theurer, 1986). O principal local de digestão do amido é o rúmen. A taxa e a extensão da digestão do amido no rúmen, influenciam a composição dos ácidos produzidos pela fermentação microbiana, $\circ \mathrm{pH}$ ruminal e a quantidade de amido disponível para digestão no intestino delgado (Simas, 1997). Quando se flocula o grão de milho ou de sorgo ocorre um aumento na digestão do amido devido ao aumento da quantidade de amido digerido no rúmen assim como do restante que alcança o intestino delgado. Pesquisas tem demonstrado que a floculação a vapor do milho ou do grão de sorgo, aumentam a porcentagem da proteína do leite e a produção de leite em vacas em lactação.

O milho e o sorgo floculados têm sido muito utilizados em rações para bovinos em confinamentos americanos, resultando em melhor eficiência alimentar devido ao melhor aproveitamento do amido (Zinn, 1991).

Pouco se sabe sobre os beneficios do milho floculado em dietas para bezerros (as) leiteiros (as), em contraste aos numerosos estudos com vacas em lactação e bovinos em confinamento, os quais têm sido demonstrado que milho floculado a vapor aumenta a digestibilidade do amido no rúmen e no trato digestivo total (Theurer, 1986). A densidade ideal de floculação para vacas 
leiteiras está entre 0,30 a $0,39 \mathrm{~kg} / \mathrm{L}$, enquanto que para bovinos em confinamento a densidade ideal é de 0,283 a $0,361 \mathrm{~kg} / \mathrm{L}$. Pelo fato de serem encontrados efeitos benéficos do processamento de grãos para bovinos de corte em confinamento, espera-se resultados similares com bezerros (as).

$O$ presente trabalho tem como objetivo avaliar um concentrado para bezerro (formulação comercial) contendo milho moído fino ou milho floculado em três densidades sobre o ganho de peso, consumo de MS e conversão alimentar e peso e idade a desmama em bezerros (as) da raça Holandesa, durante o aleitamento com leite integral ou com um sucedâneo (formulação comercial) e após a desmama. 


\section{REVISÃO DE LITERATURA}

\subsection{Características físicas e químicas do amido}

O amido é um polissacarídeo não estrutural de reserva e representa 60 a $70 \%$ da matéria seca em cereais como o milho, o sorgo, a cevada, o trigo e a aveia (Rooney \& Pflugfelder, 1986).

A estrutura das sementes (grãos) reflete sua função biológica: proteção e transporte do embrião, completando como uma fonte de energia para suprir a germinação e o crescimento inicial. O pericarpo envolve 0 embrião e 0 endosperma periférico e o córneo que contém os grânulos de amido, envolvidos por uma matriz rica em proteína. Abaixo dessas camadas está o endosperma farináceo que apresenta a maior quantidade de grânulos de amido e não está envolvido por uma matriz protéica. O amido presente neste endosperma é o mais susceptível a forças externas como a digestão ou o processamento do grão (Kotarski et al., 1992).

Os grânulos de amido são envolvidos por matrizes de proteína sendo que a digestibilidade do amido é afetada pela extensão dessa matriz protéica (Kotarski et al., 1992).

$O$ amido existe na forma de grânulos altamente organizados, nos quais moléculas de amilose e amilopectina estão ligadas por pontes de hidrogênio. A amilose é um polímero linear de unidades de $\mathrm{D}$-glicose com ligações tipo $\alpha 1-4$ 
e está presente de 0 até $80 \%$ (normalmente de 20 a 30\%) no amido, dependendo das espécies e suas variações genéticas. Já a amilopectina consiste de uma cadeia linear de resíduos de glicose $(\alpha-1,4)$, com pontos de ramificações $(\alpha-1,6)$ a cada 20 a 25 unidades, sendo mais abundante que a amilose, correspondendo a cerca de 70 a $80 \%$ da maioria do amido dos cereais (Rooney \& Pflugfelder, 1986).

Os grânulos de amido são pseudo cristais que possuem regiões organizadas (cristalina) e não organizadas (amorfa). A região cristalina compreende a amilopectina que é resistente a entrada de água e ao ataque enzimático, enquanto que a região amorfa, representada pela amilose, é menos densa que a cristalina, permitindo um movimento livre de água, sendo esse o local onde se inicia o ataque da amilase, enquanto que a hidrólise da região cristalina ocorre mais vagarosamente (Rooney \& Pflugfelder, 1986).

Os diferentes gräos de cereais produzem grânulos de amido com características próprias (tamanho, forma e propriedades). Os grânulos de amido do milho e do sorgo são similares mas resistentes à hidrólise enzimática. A superficie desses grãos inteiros, sem sofrer nenhum processamento e com o pericarpo intacto, são resistentes a ação das bactérias ruminais dificultando o acesso ao endosperma (Mc.Allister et al., 1990). A presença da proteína zeína no endosperma e a alta quantidade de óleo no gérmen podem também contribuir para a resistência do endosperma ao ataque microbiano do amido do milho.

\subsection{Processamento de grãos}

O processamento de grãos pode ser definido como "qualquer processo físico que altera a estrutura molecular original ou a composição física de um grão" (Barmore, 1994). Os tipos de processamento incluem laminação, tostagem, moagem, floculação, micronização, pipoca, colheita precoce, 
reconstituição e explosão. Quando os grãos sofrem apenas ação mecânica no processamento, ocorre alteração física, permanecendo inalterada a sua estrutura granular. Já quando submetidos a tratamentos térmicos com calor e pressão, os grânulos de amido sofrem gelatinização, quebrando as pontes de hidrogênio intra-moleculares, e ao absorverem água, incham e exsudam parte da amilose, tornando-se mais susceptiveis à degradação enzimática. A gelatinização começa na região amorfa sendo que a penetração do calor e da umidade na região cristalina ocorre mais vagarosamente. O processamento físico na presença de umidade e vapor quebra a matriz e corpos protéicos, permitindo uma maior digestão enzimática (Nocek \& Tamminga, 1991). O processo é sinérgico e o estresse gerado pelo inchaço da região amorfa ajuda na quebra dos cristais. O processamento de grãos aumenta a energia disponível no grão pelo aumento da digestibilidade ruminal e no trato digestivo total (Hale, 1973), aumentando assim a disponibilidade de energia para o animal (Orskov, 1986; Rooney \& Pflugfelder, 1986; Theurer, 1986).

No processo de floculação, os grãos de cereais são colocados em uma câmara ou compartimento, onde ficam expostos ao calor e umidade (vapor) à pressão atmosférica por 30 a 60 minutos, causando o inchaço do grão. 0 grão quente e úmido é prensado através de rolos e os grãos inchados são quebrados, formando uma pasta que se torna um floco, causando um aumento na superfície de contato, tornando o amido mais susceptível ao ataque enzimático. O processo de laminação a vapor difere da floculação quanto ao tempo de exposição no vapor ( 1 a 8 minutos) aumentando apenas a palatabilidade do grão, sem grande efeito na digestibilidade do amido (Simas, 1997)

$\mathrm{Na}$ tentativa de aumentar o valor nutritivo do milho e de outros grãos, pesquisas foram realizadas com o objetivo de se determinar $\circ$ tempo de cozimento com o vapor e sobre a densidade de floculação. Zinn (1990b), manteve a densidade de $340 \mathrm{~g} / \mathrm{L}$ do grão floculado e testou o tempo em que o 
grão permanecia sob pressão de vapor (34, 47 ou 67 minutos). Ele concluiu que manter o grão de milho por mais de 34 minutos no vapor, não aumentou o valor nutritivo do milho floculado.

A floculação de grãos é a técnica de processamento mais estudada para vacas em lactação devido principalmente a sua praticidade e custo. A floculação do grão de milho e sorgo é o processamento mais utilizado em dietas de terminação para gado de corte nos confinamentos do oeste americano estando relacionado com melhores desempenhos dos bovinos através da utilização do amido (Theurer et al., 1986; Theurer et al., 1996a). Entretanto poucas pesquisas sobre grãos processados foram realizadas com bezerros.

\subsection{Degradação do amido}

\subsubsection{Digestão ruminal}

Quando o grão é fornecido intacto ao animal, este é danificado pelo processo de mastigação aumentando a superfície de contato $e$ consequentemente a digestibilidade dos grãos, mas nem todos os grãos são afetados pela mastigação, motivo pelo qual são menos degradáveis que os grãos processados (Huntigton, 1994).

A otimização da utilização do amido pelos animais é importante principalmente pela energia contida nele, pois no rúmen, as bactérias amilolíticas digerem o amido resultando na produção de ácidos graxos voláteis (AGV) que são a maior fonte de energia para os ruminantes. A quantidade de energia extraída dos grânulos de amido é dependente da taxa e grau de digestão no rúmen. Portanto diferentes formas de processamento são utilizadas para maximizar a utilização do amido. Além disso, o processamento pode 
destruir micotoxinas e melhorar as características da mistura na dieta facilitando o manejo e aumentando o desempenho animal. Outros componentes da dieta, em especial as fontes de forragem, nivel e umidade, podem alterar a necessidade e o benefício do processamento de grãos (Owens et al., 1997).

O principal local de digestão do amido é o rúmen, sendo que o amido pode ser digerido enzimaticamente no intestino delgado (Theurer, 1986).

Kotarski et al. (1992) identificaram 15 classes de bactérias amilolíticas e caracterizaram oito enzimas amilolíticas produzidas por estas bactérias. Pelo menos algumas destas bactérias aderem e colonizam as partículas dos grãos no rúmen e produzem endo e exo enzimas que hidrolisam as ligações $\alpha 1-4$ da amilose e $\alpha 1-4$ e $\alpha 1-6$ da amilopectina. Após o amido ser degradado em maltose e glucose, as bactérias sacaroliticas fermentam esses substratos rapidamente até piruvato, e em seguida a AGVs. A proporção molar do acetato, propionato e butirato produzidos no rúmen dependem do tipo de carboidrato aí fermentado, tempo e extensão da degradação, espécie de bactéria e ambiente ruminal (Van Soest, 1994). Os AGVs. produzidos através da fermentação ruminal, são quase totalmente absorvidos no rúmen, retículo e omaso.

A digestibilidade do amido é afetada pela sua composição e forma física, interação proteína-amido, integridade celular do conteúdo do amido, fatores anti-nutricionais (inibidores enzimáticos, fitatos, lecitinas e taninos) e a forma física do alimento (Rooney \& Pflugfelder, 1986). A digestibilidade da proteína e do amido estão diretamente relacionados. Em geral, o amido dos cereais é mais facilmente digerido do que o amido de raízes e tubérculos (Rooney \& Pflugfelder, 1986).

O grão inteiro com o pericarpo intacto é altamente resistente a digestão em ruminantes (Mc.Allister et al., 1990). Owens et al. (1986), em sua revisão, relataram que a digestibilidade ruminal do grão de milho intacto é de $58 \%$, enquanto que a digestibilidade no trato digestivo total é de $91,7 \%$. 
O principal efeito do grão processado é transferir o local de digestão do amido do intestino para o rúmen, e também aumentar a digestão em ambos compartimentos. Deste modo, quanto menor o escape ruminal do amido, maior será a sua utilização total. A energia prontamente disponivel da fermentação do amido também é aproveitada para a síntese de proteína microbiana em resposta à digestibilidade do amido (Theurer, 1986).

Em média, $98 \%$ do amido do grão de sorgo processado à vapor, micronizado ou reconstituído é digerido no trato digestivo total, enquanto que a digestão total do laminado a seco é de $91 \%$. Aproximadamente $40 \%$ do milho inteiro pode escapar da fermentação ruminal. Entretanto, se o milho for submetido a vapor ou cozido anteriormente, quase todo o amido pode ser fermentado no rúmen. A digestibilidade total do amido do milho e do sorgo processados são similares (98 vs. $99 \%$ ), visto que o escape ruminal é menor para o milho (14\%) do que para o sorgo (24\%) (Theurer, 1986). A utilização do amido no trato digestivo de ruminantes depende de vários fatores, incluindo 0 tipo de grão, espécie animal, método de processamento e composição da dieta.

O tipo de grão e o processamento alteram o local de digestão do amido e a utilização dos nutrientes pelo animal. No rúmen, os açúcares liberados pelas enzimas amilolíticas são substratos para muitas espécies de bactérias, assim os açúcares são rapidamente fermentados a ácidos graxos voláteis e gás (Huntington, 1994). Quanto mais acessivel for o amido para as bactérias, mais rápida será a taxa de fermentação, e haverá maior produção de ácidos graxos voláteis. O processamento do milho resulta em maior digestibilidade ruminal quando comparado ao milho moído, devido ao aumento da fermentação ruminal (Galyan et al., 1976).

Estudos realizados com gado de corte demonstraram que o amido da dieta com $86 \%$ de degradabilidade no rúmen, apresentou maior digestibilidade no intestino delgado, quando comparados a dietas com $65 \%$ de digestibilidade ruminal (72 vs.. $58 \%$ ). Aumentando a digestibilidade ruminal do amido diminuiu 
aproximadamente $50 \%$ a quantidade de amido dietético que alcança o intestino delgado (22 vs. $10 \%$ do consumido) e do intestino grosso (4 a $2 \%$ do consumido) (Theurer et al., 1996a). Os mesmos autores, em sua revisão comparando os efeitos do grão de sorgo laminado a seco e o floculado, verificaram que o floculado aumentou a digestibilidade ruminal do amido em $40 \%$ (76 vs. $54 \%$ ) (Theurer et al., 1996b). Consequentemente, o amido digerido pós rúmen, representado como a porcentagem de amido consumido, diminuiu em $40 \%$ com a floculação, enquanto que a digestibilidade total do amido aumentou em $10 \%$ para o floculado (94 vs. $85 \%$ ). Enfim, grão de sorgo ou milho floculados melhoram a digestibilidade total do amido pelo aumento da proporção de amido dietético digerido dentro do rúmen e também pelo aumento da digestibilidade da pequena quantidade de amido que alcança 0 intestino delgado.

\subsubsection{Digestão no intestino delgado}

O amido que escapa à degradação ruminal passa para o intestino delgado onde pode ser digerido enzimaticamente como ocorre em outras espécies animais (Huntington, 1994). O pâncreas secreta a enzima $\alpha$-amilase, que irá hidrolisar amilose e amilopectina em oligossacarídeos de duas a três unidades e $\alpha$-dextrinas, e uma pequena quantidade de glucose. As moléculas de glucose são absorvidas pelos enterócitos enquanto que as outras são hidrolisadas nas microvilosidades intestinais através de oligossacaridases, e absorvidas através de transporte ativo com sódio (Gray, 1992). A digestão do amido pode ser limitada no intestino devido a falta de amilase e pela capacidade limitada de absorção da glicose (Orskov, 1986; Owens, 1986). Zinn et al. (1995) concluíram que o fator limitante que influencia na digestão pósruminal do amido é a disponibilidade deste no intestino. Por outro lado, Harmon (1993), em sua revisão, propôs que a secreção e produção de enzimas que 
digerem amido no intestino respondem mais a quantidade de energia consumida pelo animal do que a quantidade de amido dietético. Essa capacidade limitada de digestão do amido no intestino delgado é minimizada pelo processamento que pode diminuir a quantidade de amido presente nos intestinos, consequentemente aumentando a porcentagem do amido ali digerido (Theurer et al. 1996b). Segundo Nocek \& Taminga (1991), a ingestão de amido está correlacionada positivamente com o consumo de amido degradável no rúmen, o amido que escapa do rúmen, e com a digestão do amido no trato digestivo total e no intestino. A extensão do amido digerido no rúmen está negativamente correlacionado com a proporção de amido dietético digerido no intestino delgado, e este está altamente correlacionado com a digestibilidade total do amido.

A extensão do amido digerido no rúmen e a síntese de proteína microbiana podem alterar as quantidades e os tipos de aminoácidos e a quantidade de glucose disponível para a absorção no intestino delgado em ruminantes. $\mathrm{O}$ grão de milho ou sorgo floculados podem aumentar a produção de leite ( 8 a 10\%) e a produção de proteína do leite em 8 a 16\%. Isto é devido à maior proporção de amido dietético fermentado no rúmen e à maior absorção de energia (AGVs.), aumentando a digestibilidade da menor fração do amido que alcança o intestino delgado e a digestão total do amido. Esse aumento da degradação ruminal do amido duplica a quantidade de uréia reciclada para as vísceras, aumentando a proteína microbiana que alcança o intestino delgado. Desse modo, aumentam as proporções de ácido propiônico no rúmen e aumentam os aminoácidos que chegam na glândula mamária (Theurer, 1996b). 


\subsubsection{Digestão no intestino grosso}

$\mathrm{O}$ amido que passa para o intestino grosso, especificamente no ceco e cólon, sofre fermentação microbiana resultando na produção de AGVs., síntese de proteína microbiana a partir do nitrogênio da digesta e entrada de uréia do sangue no intestino grosso (Orskov, 1986). Os AGVs. produzidos são absorvidos no intestino grosso e a proteína microbiana é excretada pelas fezes.

A quantidade de amido digerida pós-rúmen é menor para os grãos floculados, reconstituídos ou micronizados comparados aos inteiros ou laminados, ou seja, esse amido que chega ao intestino grosso é mais digestível que o amido dos grãos pouco ou não processados. Zinn et al. (1995), realizaram um estudo com novilhos fistulados $e$ avaliaram o consumo de matéria seca comparando o milho laminado com o milho floculado, e concluiram que a digestão pós-ruminal do milho laminado (64\%) foi menor que a do milho floculado (91\%).

\subsection{Efeito da densidade do grão floculado}

A qualidade do grão floculado é medida através da densidade $(\mathrm{kg} / \mathrm{L}$ ou g/L) e reatividade do floco (Joy et al., 1997). A digestibilidade dos grãos floculados ou laminados pode diferir com a intensidade do processamento. No processo de floculação, ao aumentar o espaçamento entre os rolos compressores, os flocos se tornam mais grossos devido à menor pressão dos rolos no grão. Aumentando o tempo no vapor antes da pressão entre os rolos tem-se flocos mais resistentes a quebra. Desse modo a densidade é utilizada como parâmetro da floculação. Outros índices incluem a gelatinização 
(medição microscópica) e taxa de digestão por leveduras ou enzimas de animais (Zinn, 1990b).

\subsubsection{Novilhos de corte}

Devido aos custos também aumentarem com o nivel de processamento, tem sido de grande interesse em se estabelecer a relação entre o nível de floculação através da densidade e a resposta no desempenho de bovinos de corte (Swingle et al., 1993). A densidade de grãos floculados na indústria americana varia de 283 a $360 \mathrm{~g} / \mathrm{L}$, resultando em grande diferença no gasto de energia e nos custos de processamento, assim como no desempenho animal.

Segundo Swingle (1992), devido a consistente relação linear entre densidade de floculação e índices laboratoriais da disponibilidade do amido, seria lógico assumir que relações similares existiriam entre a densidade, digestão do amido "in vivo" e eficiência alimentar para gado de corte, mas esses resultados não são encontrados em todos os trabalhos.

Xiong et al. (1991), testando três densidades de sorgo floculado (283, 360 e $437 \mathrm{~g} / \mathrm{L}$ ) em novilhos, verificaram que não houve diferença no ganho de peso diário em resposta a densidade do grão, mas houve efeito linear no consumo de matéria seca diária, sendo que os animais que consumiram grãos do maior nivel de processamento (menor densidade do grão) consumiram menos matéria seca, e a eficiência alimentar foi maior para os grãos floculados de densidade menor: 15,7, 16,5 e 16,9 (kg ganho de peso/100kg de CMS) para 437,360 e $283 \mathrm{~g} / \mathrm{L}$ respectivamente. Já, Reinhardt et al. (1997) verificaram que com o aumento da densidade do sorgo floculado $(283,322,360 \mathrm{~g} / \mathrm{L})$ houve resposta linear no aumento de consumo de matéria seca e no ganho de peso médio diário. A eficiência alimentar foi melhor nos animais que consumiram sorgo floculado com densidade de $360 \mathrm{~g} / \mathrm{L}$. A redução da eficiência alimentar para os animais que receberam o sorgo floculado com baixa densidade (283 
g/L), foi em parte devido a redução de consumo de matéria seca, resultando em uma maior proporção do consumo total de energia metabolizável para mantença comparada aos que receberam a densidade maior. Trabalhos de Zinn (1990a) também obtiveram respostas similares. Theurer et al. (1999) estudaram a interação entre o tipo de volumoso fornecido a novilhos e três densidades de sorgo floculado (386, 322 e $257 \mathrm{~g} / \mathrm{L}$ ) e verificaram que não houve efeito de interação entre a fonte de volumoso e as densidades no desempenho ou na avaliação de carcaça, sendo que o aumento progressivo do nivel de floculação resultou em diminuição linear no consumo de matéria seca, não havendo diferenças no ganho de peso diário.

Ao realizar uma revisão comparando as densidades dos grãos da cevada, milho e sorgo floculados, Owens et al. (1997) verificaram que os flocos de menor densidade (menor de $280 \mathrm{~g} / \mathrm{L}$ ) tenderam a diminuir o consumo de matéria seca enquanto aumentava o valor de energia metabolizável do grão. Mas a eficiência alimentar nunca foi superior comparada a eficiência alimentar com as densidades maiores (maior que $280 \mathrm{~g} / \mathrm{L}$ ), devido ao baixo consumo de matéria seca e de ganho de peso médio diário.

Segundo Swingle et al. (1999), os ganhos de peso diários não diminuíram quando foi fornecido sorgo floculado com densidade de $412 \mathrm{~g} / \mathrm{L}$ comparado a $360 \mathrm{~g} / \mathrm{L}$. Considerando o aumento nos custos do processamento, $360 \mathrm{~g} / \mathrm{L}$ seria a densidade mais eficiente, devido as melhores conversões alimentares que ocorreram quando a densidade foi reduzida de 412 para $360 \mathrm{~g} / \mathrm{L}$.

O grão intensivamente floculado, pode causar aumento na ocorrência de distúrbios digestivos devido à rápida taxa de fermentação do amido (Zinn, 1990a). A queda do $\mathrm{pH}$ e sua maior duração no rúmen devido ao excesso de consumo de grão mais intensivamente processado resultaram no aumento da severidade de acidose (Reinhardt et al., 1997), mas ao realizar a avaliação de 
carcaça não foram constatados abscessos no fígado em resposta as densidades dos grãos (Xiong et al., 1991; Reinhardt et al., 1997).

Quanto mais fino for o floco, maior será a gelatinização ou solubilidade e a taxa de hidrólise do amido (Swingle et al., 1999). A disponibilidade do amido, medido através de métodos laboratoriais, apresentou aumento linear e quadrático em resposta ao aumento da intensidade de processamento através da diminuição da densidade, do mesmo modo que a hidrólise enzimática do amido do grão de sorgo aumentou linearmente quando se diminuiu a densidade de 412 a $257 \mathrm{~g} / \mathrm{L}$. A diminuição da densidade proporcionou um aumento na digestibilidade do amido no rúmen $(91,6 \%$ vs. $83,0 \%$ para 257 e $412 \mathrm{~g} / \mathrm{L}$ ), intestino delgado ( $76,1 \%$ vs. $72,9 \%$, representado em porcentagem de entrada do amido no intestino), intestino grosso ( $70,3 \%$ vs. $73,5 \%$ ) e no trato digestivo total (99,4\% vs. 98,9\%) (Swingle et al., 1999; Zinn, 1990a). Consequentemente, o fluxo de amido para o duodeno, ileo e fezes, diminuiu com a diminuição da densidade.

Diminuindo a densidade do grão de milho floculado de 420 para $300 \mathrm{~g} / \mathrm{L}$, Zinn (1990a) demonstrou que houve um aumento na susceptibilidade do amido à digestão "in vitro" e um aumento na utilização de nitrogênio, na porcentagem de amido digerido pós rúmen e na digestibilidade total.

\subsubsection{Vacas leiteiras}

Para vacas leiteiras, o processamento excessivo dos grãos de cereais, pode causar a diminuição na gordura do leite (devido as proporções de ácidos graxos voláteis), na digestibilidade da fibra e no consumo de matéria seca (Moore et al., 1992). Segundo Joy et al. (1997), a digestibilidade aparente do amido no rúmen foi numericamente maior para o milho floculado a $310 \mathrm{~g} / \mathrm{L}$ comparada ao milho laminado, mas o milho floculado a $390 \mathrm{~g} / \mathrm{L}$ obteve pequena diferença inferior ao milho laminado, sugerindo que $\circ$ nivel de 
processamento foi uma importante consideração em dietas para vacas em lactação. Por outro lado, Plascentia \& Zinn (1996), ao compararem a influência da densidade do milho floculado (260, 320 e $390 \mathrm{~g} / \mathrm{L})$ nas características ruminais e no trato digestivo de vacas fistuladas em lactação, verificaram que a digestibilidade do amido melhorou com o nível de processamento. A digestibilidade da fibra $e$ as proporções dos ácidos graxos voláteis $e$ consequentemente a diminuição do teor de gordura do leite foram negativamente afetados quando o milho foi floculado muito intensamente. Desse modo, concluíram que a densidade ideal do milho floculado para vacas em lactação consumindo dietas com $45 \%$ de feno de alfafa está entre 320 e $390 \mathrm{~g} / \mathrm{L}$.

Estudando o efeito de cinco tipos de processamento do milho (moído fino $580 \mathrm{~g} / \mathrm{L}$; moído grosso $618 \mathrm{~g} / \mathrm{L}$; milho floculado $309 \mathrm{~g} / \mathrm{L} ;$ milho floculado $360 \mathrm{~g} / \mathrm{L}$ e milho laminado a vapor $490 \mathrm{~g} / \mathrm{L}$ ) no desempenho da lactação de vacas de leite e na digestibilidade dos nutrientes, Yu et al. (1998) verificaram que a ingestão de matéria seca para o milho moído fino foi menor em relação aos outros tratamentos, mas não foi afetada em resposta a densidade no milho floculado, no entanto, a resposta à eficiência alimentar para o milho moído fino foi a melhor. A média de produção de leite aumentou em $2,5 \mathrm{~kg} /$ dia para as vacas alimentadas com milho floculado a $360 \mathrm{~g} / \mathrm{L}$ em relação as vacas alimentadas com milho moído grosso, milho floculado $309 \mathrm{~g} / \mathrm{L}$ e milho laminado a vapor. A porcentagem de gordura no leite foi menor para o tratamento milho floculado $309 \mathrm{~g} / \mathrm{L}$ quando comparado com milho laminado e milho moído grosso. A porcentagem de proteina do leite não foi diferente entre os tratamentos. A floculação e a moagem fina aumentaram a digestibilidade do amido no trato digestivo total mas apresentaram efeito negativo na digestibilidade da fibra. 


\subsection{Processamento de grãos na dieta de bezerros}

\subsubsection{Desenvolvimento do rúmen}

O consumo de alimento sólido nas primeiras semanas de vida do bezerro, é o fator mais importante na transição de pré-ruminante para o ruminante adulto. Essa transição envolve mudanças morfológicas nos tecidos digestivos, como também mudanças sistêmicas do metabolismo (Huber et al., 1984). O consumo de alimentos sólidos além de estimular o desenvolvimento do rúmen, permite também o aparecimento da população microbiana, resultando em alta atividade metabólica do rúmen (Anderson et al., 1987a).

No nascimento, o rúmen e $\circ$ retículo são pequenos e aumentam rapidamente de tamanho se o animal consumir alimentos sólidos, mas se o bezerro ingerir apenas dieta líquida, esses dois compartimentos permanecerão pequenos (Morril, 1992). O peso e o volume do rúmen e retículo aumentam substancialmente quando bezerros consomem apenas feno comparado ao consumo de concentrado.

As mudanças morfológicas devido ao crescimento dos tecidos suprem a necessidade da superfície para absorção dos produtos finais da digestão microbiana que ocorre no rúmen com o aumento do consumo de alimentos sólidos. Os produtos finais da fermentação, responsáveis pelo crescimento e desenvolvimento do tecido ruminal (papilas) são os ácidos graxos voláteis (AGVs.), em particular os ácidos butírico e propiônico. A concentração de AGVs. atinge valores semelhantes aos dos animais adultos entre a $6^{a}$ e $8^{a}$ semana de vida. Bezerros desmamados tendem a apresentar maiores concentrações de AGVs., do que bezerros não desmamados de mesma idade e durante a $3^{\mathrm{a}}$ e $4^{\mathrm{a}}$ semana há aumento na proporção molar de butirato a partir da fermentação do lactato, causado pelo abaixamento do $\mathrm{pH}$ entre a $3^{\mathrm{a}} \mathrm{e}$ $7^{\mathrm{a}}$ semana de vida (Anderson et al., 1987a). A estimulação contínua de AGVs. 
é necessária para a manutenção das papilas, pois ao mudar de uma dieta sólida para uma com apenas leite, poderá causar a regressão das papilas (Morril, 1992).

O milho é o cereal mais utilizado em dietas iniciais para bezerro, pois é um excelente alimento devido a sua alta digestibilidade no rúmen e no trato digestivo total. $O$ fato de alguns bezerros não aceitarem a dieta sólida, acarreta em baixo desempenho no periodo pós-desmama, que pode ser devido à incapacidade do bezerro em utilizar eficientemente as fontes de amido (Huber et al., 1961; Huber et al., 1968), mas para Leibholz, citado por Lallès (1993) o desmame abrupto de bezerros para aumentar o consumo de concentrado permite o rápido desenvolvimento do rúmen e da capacidade digestiva do amido, sendo que após a $9^{a}$ semana de vida o amido é quase totalmente digerido $(99,4 \%)$, principalmente no rúmen $(91,6 \%)$. Lallès (1993), estudando a digestão do amido do milho e da ervilhaca no rúmen e no intestino de bezerros entre $9^{a}$ a $20^{a}$ semanas de vida, concluiu que 0 amido foi digerido quase totalmente a partir da $10^{\mathrm{a}}$ semana de vida, sendo degradado principalmente no rúmen. $\mathrm{O}$ autor concluiu também que $\mathrm{o}$ amido da dieta contendo ervilhaca foi menos degradado no rúmen que o amido do milho.

No animal desmamado, consumindo apenas alimento sólido, apresenta uma tendência na redução de doenças, especialmente diarréia. Os custos com alimentação e mão de obra também diminuem substancialmente quando o bezerro faz parte do programa de alimentação sólida do rebanho (Morril, 1992).

\subsubsection{Forma física da ração inicial}

Conforme mencionado anteriormente, o desenvolvimento do rúmen do bezerro em aleitamento é largamente influenciado pelo consumo de alimentos sólidos e produtos finais da digestão, sendo que só haverá sucesso se o consumo de ração concentrada for de boa qualidade e de aceitação fácil pelo 
bezerro. O consumo de ração inicial para bezerros colabora com $65 \%$ da variação do ganho de peso total do animal e as estimativas do consumo de nutrientes digestíveis causam $88 \%$ da variação do peso metabólico final (Kertz et al., 1979). A adição de ração inicial altamente palatável para bezerros num programa de desmame precoce aceleram o consumo dos alimentos sólidos (Anderson et al., 1987b).

A forma física da dieta ou o tamanho da partícula é extremamente importante na preparação de ração inicial para bezerros. Alimentos muito finos resultam em diminuição do consumo e podem se prender entre as papilas, causando paraqueratose. A forma física da ração também está diretamente relacionada com as diferenças anatômicas da morfologia do rúmen. Rações altamente digestíveis (concentrados) podem resultar em maiores quantidades de substrato fermentável no rúmen. Isso provavelmente resultaria em hiperplasia das células, aumentando o peso da mucosa ruminal (Nocek et al., 1984).

Diferenças no consumo de alimentos similares podem ser atribuidas a preferências baseadas na palatabilidade ou em alguma outra sensação (textura, pó, etc); maneira de como o alimento é oferecido (posição ou altura do cocho); tamanho do alimento que chega ao rúmen; taxa de passagem no trato digestivo ou a capacidade intestinal, além de outros fatores (Davis \& Drackley, 1998). Bush (1989) forneceu diferentes cereais em dietas iniciais para bezerros e concluiu que houve preferências dos bezerros, sendo que o consumo foi maior para a dieta que continha cevada, seguido de milho e aveia, sendo que essa preferência afetava o desempenho do bezerro.

Morril et al. (1981) avaliaram o consumo de dieta inicial na forma de pelete e extrusada. Eles verificaram que a dieta extrusada causou diminuição do consumo diário $(2,4$ vs. $1,4 \mathrm{~kg})$ durante a terceira semana. Essa diferença foi atribuida ao sabor alterado pela extrusão, ao efeito no rúmen devido ao baixo 
volume de consumo ou à alteração da forma física da dieta, criando um efeito negativo quando o animal mastigava o alimento.

Nos Estados Unidos o principal motivo da aceitação de milho floculado pelos produtores em dietas iniciais para bezerros é 0 aumento da digestibilidade do amido, palatabilidade e aceitação do bezerro. A densidade do milho floculado é considerada como um parâmetro importante ao adotá-lo na dieta inicial para bezerros. Se o floco for muito grosso, ocorre uma diminuição da palatabilidade, enquanto que no excessivamente fino, os flocos se quebram e formam grânulos muito finos, diminuindo a palatabilidade (Barmore, 1994).

A maior parte dos trabalhos conduzidos com grãos floculados envolvem animais em lactação ou animais em confinamento, havendo poucos com bezerros de modo que os resultados são conflitantes. Shuh et al. (1970), foram os primeiros a testar grãos floculados para bezerros. Eles compararam o sorgo e a cevada, ambos laminados e floculados a vapor, na desmama de bezerros Holandeses com 24 e 35 dias de vida. O ganho de peso diário não diferiu entre os tratamentos $(P>0,05)$ mas o sorgo e a cevada floculados tenderam a melhorar o ganho de peso e a conversão alimentar para as duas idades de desmama. Para o grão de sorgo, a floculação melhorou a conversão alimentar em $9 \%$ para bezerros desmamados aos 35 dias e em $11 \%$ para 24 dias $(1,13$ e $1,26 \mathrm{~kg}$ MS consumido/kg ganho de peso, respectivamente), entretanto, a conversão alimentar foi melhor para a cevada floculada $(0,92)$. Em geral, a cevada floculada tendeu a melhorar o ganho de peso e a conversão alimentar comparada com o sorgo floculado ou laminado a vapor. Em outro experimento, os mesmos autores (Shuh et al., 1971) compararam o sorgo floculado a vapor, mantido a pressão atmosférica por $25 \mathrm{~min}$ a $102^{\circ} \mathrm{C}$, com o sorgo processado a pressão, submetido a vapor por $1,5 \mathrm{~min}$. Os autores verificaram que não houve diferença significativa $(P>0,05)$ entre os tratamentos, entretanto, houve uma tendência dos animais alimentados com o sorgo floculado consumirem mais 
ração inicial durante os 10 dias após o desmame. Waldern \& Fisher (1978) estudaram os efeitos da cevada laminada e floculada a vapor em bezerros até atingirem $115 \mathrm{~kg}$ de peso vivo. Eles verificaram que animais que consumiram cevada floculada demoraram mais tempo para alcançar os $115 \mathrm{~kg}$ (106,5 vs. 103,9 dias) e apresentaram ganho de peso também menor (687 vs. $716 \mathrm{~g} / \mathrm{dia}$ ) comparado a cevada laminada a vapor.

Segundo Maiga et al. (1994) o alto consumo de matéria seca com baixa degradabilidade ruminal de carboidratos e proteínas resultou em melhor ganho de peso em bezerros durante a fase do nascimento à $12^{\mathrm{a}}$ semana de vida, provavelmente devido a maior quantidade de nitrogênio e carboidrato dietético que alcança 0 intestino delgado para digestão e absorção. Entretanto, Olivares-Reyna et al. (1992) encontraram melhores desempenhos em bezerros que receberam dietas com fontes de alta degradabilidade ruminal de proteína e baixa de amido. Em um experimento com milho e farelo de soja para bezerros, Abdelgair et al. (1996a) verificaram que o milho tostado $\left(135^{\circ} \mathrm{C}\right)$ e farelo de soja ou o farelo de soja tostado a $138^{\circ} \mathrm{C}$, fornecidos no pelete junto com os outros ingredientes, tenderam a aumentar todas as variáveis estimadas no experimento (consumo, ganho de peso, eficiência alimentar e altura de cernelha) quando comparados ao farelo se soja tostado a $146^{\circ} \mathrm{C}$, demonstrando o melhor desempenho quando há sincronia entre as fontes de proteína e de carboidrato com o mesmo grau de disponibilidade no rúmen. Os mesmos autores (Abdelgair et al., 1996b) em outro experimento similar, tiveram respostas diferentes, ou seja, não seria necessário haver sincronia entre a degradabilidade da proteína bruta e da fonte de amido, pois o desempenho dos bezerros foi semelhante. Essa contradição, os autores atribuíram a maior gelatinização do amido do milho conglomerado (água foi adicionada ao grão para elevar a umidade para $25 \%$ e então peletizado com os outros ingredientes), comparada ao milho tostado utilizado no trabalho anterior. A presença de amido altamente gelatinizado pode melhorar o metabolismo 
ruminal dos microrganismos, aumentando a contribuição da proteína microbiana, como também de energia na forma de AGVs. para os bezerros.

Comparando o milho tostado com o milho floculado em 132 bezerros leiteiros, Abdelgair et al. (1993) demonstraram que o consumo tendeu a aumentar para o milho floculado, sustentando a idéia de que o processamento do milho a calor e umidade pode aumentar a palatabilidade do grão.

Stewart \& Schingoethe (1984) estudaram o aumento da densidade energética de rações iniciais para bezerro através da utilização de amido e de gordura. A fonte de amido utilizado foi o grão de milho laminado e a fonte de gordura foi o grão de soja extrusado. Essas dietas foram formuladas para apresentarem 3,48 Mcal/kg de MS, enquanto que a dieta controle apresentou 3,31 Mcal $/ \mathrm{kg}$ de MS. Eles observaram que o consumo médio diário e o ganho de peso médio diário foram similares entre os tratamentos. A dieta controle teve maior digestibilidade e maior energia digestivel do que as dietas ricas em amido ou de gordura, indicando que não havia nenhum benefício no desempenho de bezerros em resposta ao aumento do amido através do milho ou de gordura através de grãos de soja extrusado em dietas iniciais para bezerros.

Abdelgadir \& Morril (1995) avaliaram a presença de grão de sorgo cru, tostado ou conglomerado em dietas iniciais para bezerros do nascimento a $8^{a}$ semana de vida e observaram que o tipo de processamento do grão de sorgo não afetou o consumo nem o ganho de peso médio diário, mas o consumo total de matéria seca foi maior para bezerros que receberam o grão de sorgo cru ou tostado. Essa preferência foi atribuída a baixa palatabilidade do grão de sorgo conglomerado. O grão de sorgo tostado aumentou a eficiência alimentar em $5 \%$, e o conglomerado em $11 \%$ após a desmama em relação ao sorgo cru, devido ao aumento de digestibilidade do grão processado. As concentrações e porcentagens molares de AGVs. no rúmen, amônia ruminal, lactato ruminal, glucose plasmática e uréia plasmática não foram afetadas pelos tratamentos. 
Quando o grão de sorgo laminado a vapor foi comparado ao extrusado, Morrill et al. (1970) verificaram que devido a maior gelatinização do amido, o sorgo extrusado foi melhor aproveitado pelo bezerro que o sorgo laminado a vapor. A gelatinização do amido através da extrusão do grão de sorgo, melhorou a digestibilidade da energia em bezerros após a desmama comparada a do sorgo peletizado (Daniels et. al, 1978).

\subsection{Sucedâneo}

A criação de bezerros, em regime de aleitamento natural ou artificial é caracterizada por alto custo (até $80 \%$ do custo total é gasto com leite integral) e altos índices de morbidade e mortalidade, que podem chegar a $20 \%$ (Liziere \& Campos, 1992). O controle da quantidade de leite fornecida aos bezerros, a substituição do leite por sucedâneo e a utilização de concentrados iniciais têm sido apontados como práticas eficientes na redução de custos com alimentação de bezerros (Barmore, 1994).

Bezerros jovens são sensiveis à qualidade da proteína nas dietas e apenas proteínas altamente digestiveis, com um perfil adequado de aminoácidos são desejáveis nos sucedâneos de leite (Drean et al., 1998).

A soja é um dos poucos vegetais que contém proteína com composição de aminoácidos razoavelmente balanceada (Campos \& Silva, 1986), e como substituto da proteína láctea é a fonte protéica mais usada e estudada. Entretanto, a inclusão de produtos de soja em sucedâneos do leite tem mostrado resultados inferiores aos obtidos com leite, sendo viáveis somente se forem convenientemente processados para eliminar os fatores antinutricionais e substâncias que inibem sua utilização (Abrahão, 1980).

Os quatro principais subprodutos da industrialização da soja, já testados no preparo do leite para bezerros são: farelo de soja, farinha de soja, 
concentrado protéico de soja e proteína isolada de soja, que apresentam, respectivamente, $45,60,70$ e $90 \%$ de proteína bruta e $45,35,25$ e $5 \%$ de carboidratos (Campos \& Silva, 1986).

\subsubsection{Digestão no abomaso}

No bezerro pré-ruminante, a digestão processa-se como nos monogástricos, sendo que, do nascimento até a terceira semana de vida a dieta deve ser fornecida na forma líquida e conter nutrientes que possam ser digeridos pelo sistema enzimático do animal, ou serem absorvidos sem alteração (Lucci, 1989).

O leite e seus substitutos consumidos pelo bezerro pré-ruminante, na forma líquida, são conduzidos diretamente ao abomaso, por meio da goteira reticular. No abomaso, ocorre a coagulação do leite e o início da digestão da proteína e da gordura. A primeira enzima digestiva adicionada à dieta é a esterase pré-gástrica, secretada em grandes quantidades, principalmente, pelas glândulas palatinas e outras glândulas salivares (Davis \& Drackley, 1998).

No abomaso, as principais secreções são de ácido clorídrico $(\mathrm{HCl})$, pepsinogênio e pró-renina. A formação de um coágulo consistente, no abomaso, previne o fluxo excessivo do alimento e nutrientes para o intestino delgado logo após a alimentação, o que poderia predispor o crescimento de organismos patogênicos. A falta de coagulação acelera o fluxo de lipídios para o intestino, normalmente retidos na matriz protéica, afetando, desta forma, a digestibilidade das proteínas, dos lipídios e dos minerais (Lyford \& Huber, 1988). 


\subsubsection{Digestão no intestino delgado}

Após a pré-digestão no abomaso, ocorre a hidrólise da proteína dietética a pequenos peptídios contidos no intestino delgado por ação da tripsina, da quimiotripsina e das carboxipeptidases, presentes no suco pancreático como enzimas inativas, e por várias peptidases, secretadas no intestino ou presentes nas células da mucosa intestinal (Campos et al., 1982).

Bezerros alimentados com sucedâneos do leite contendo $50 \%$ de proteínas de peixe ou de soja, produziram menos tripsina, quimiotripsina, protease total e ribonuclease, porém mais lipase, durante 12 horas após a ingestão em relação a bezerros alimentados apenas com proteinas lácteas (Lyford \& Huber, 1988). A redução na secreção pancreática de tripsina e quimiotripsina tem sido apontada como uma possivel explicação para a baixa digestibilidade da proteína, observada em bezerros, alimentados com substitutos do leite contendo fontes protéicas não lácteas. Isso sugeriu a possibilidade de suplementação, ou a pré-digestão destas proteínas com enzimas proteoliticas em substitutos do leite (Jenkins, 1981).

O bezerro, nas primeiras semanas de vida, tem uma capacidade limitada de digerir carboidratos exceto de lactose, tornando-se necessária a presença de lactose em sua dieta (Campos, 1993). Pouca ou nenhuma digestão ocorre com a sacarose, a maltose ou o amido. A frutose é pouco absorvida, e sua presença em grandes quantidades causa diarréias severas. A atividade da lactase intestinal em bezerros é alta ao nascer, mas reduz-se a um quarto durante os primeiros oito dias de vida, enquanto a atividade da maltase, inicialmente baixa, aumenta $40 \%$ nesse periodo (Lyford \& Huber, 1988).

Até $10 \%$ de amido pode ser utilizado no sucedâneo, sendo que níveis mais elevados podem provocar diarréias (Huber, 1968). O amido fica retido no coágulo que se forma no abomaso, havendo pequena passagem desse nutriente para o intestino. A secreção da amilase é muito pequena até a 
terceira semana de vida, mas aumenta rapidamente após essa idade (Morril et al., 1970)

\subsubsection{Digestibilidade da dieta liquida e desempenho dos bezerros}

A substituição da proteína láctea por outras fontes protéicas, em dietas líquidas para bezerros resulta, na maioria das vezes, em redução no desempenho dos animais, dependendo da fonte protéica e do nível de substituição adotados. Isto parece ser conseqüência, principalmente da redução da digestibilidade intestinal da proteína (Làlles, 1993). A substituição da proteína do leite por grandes quantidades de concentrado protéico de soja diminui a digestibilidade dos nutrientes e o desempenho dos bezerros (Dean et al., 1998). Este fato é devido baixa susceptibilidade da proteína da soja com a caseína causando rápido esvaziamento do abomaso devido a ausência de coagulação (Caugant et al., 1994).

Nitsan et al. (1971), forneceram sucedâneo com proteínas de soja crua, parcialmente aquecida $\left(120^{\circ} \mathrm{C}\right.$ durante $5 \mathrm{~min}$ ) ou aquecida $\left(120^{\circ} \mathrm{C}\right.$ por $25 \mathrm{~min}$ ) para bezerros. Os animais que foram alimentados com proteinas de soja crua ou parcialmente aquecida tiveram menor ganho de peso que aqueles alimentados com a soja aquecida, e estes apresentaram $35 \%$ do ganho de peso daqueles que receberam proteína láctea, nos primeiros 10 dias, e $75 \%$ do $11^{\circ}$ ao $30^{\circ}$ dia de idade. Para os bezerros que receberam proteína de soja crua, ou levemente aquecida, nos primeiros 30 dias, a utilização de proteína láctea, ou proteína de soja aquecida após este período, representou aumentos significativos nas suas taxas de ganho de peso. Com o aumento da idade, verificou-se melhoria no desempenho de bezerros, alimentados com proteínas não lácteas.

Em outro trabalho, Nitsan et al. (1972) verificaram que a proteína concentrada de soja permitiu ganhos de peso de 68 a $81 \%$ daqueles obtidos 
com proteína láctea. O fornecimento de concentrados e feno suplementar à dieta líquida reduziu as diferenças do ganho de peso entre as dietas líquidas, exceto quando a proteína de soja não foi completamente tostada. Aumentos na ingestão de matéria seca e no ganho de peso vivo com o avanço da idade, foram também observados por Mir et al. (1991), quando fizeram a substituição da proteína láctea dos sucedâneos, por proteína de soja, processadas por meio de tostagem, extrusão, extração com etanol, ou fermentação, a partir do $6^{\circ}, 18^{\circ}$ ou do $30^{\circ}$ dia de vida dos bezerros.

Diferenças no ganho de peso, entre tratamentos com leite integral e sucedâneos, podem aumentar com a idade, quando as dietas são fornecidas como percentagem do peso vivo. Em função dos maiores ganhos iniciais, os bezerros aleitados com leite integral, passam a receber maiores quantidades do alimento nas semanas subseqüentes, aumentando cada vez mais as diferenças, em relação aos que estão recebendo quantidades menores de um alimento de qualidade inferior. O desempenho de bezerros, criados com sucedâneos do leite contendo proteinas de peixe, ou de soja, depende das características do produto, da proporção substituída, da percentagem de proteína bruta do sucedâneo, da idade do bezerros e do concentrado inicial utilizados no programa de alimentação (Huber \& Campos, 1982).

De acordo com Funaba et al. (1994), durante o período de aleitamento, a energia e a proteína absorvidas no intestino delgado vêm do leite ou do sucedâneo. Com a desmama, observam-se mudanças fundamentais na disponibilidade de nutrientes para o bezerro ruminante, em que a energia e a proteína passam a ser, principalmente, de origem da fermentação ruminal, e a proteína absorvida no intestino, consiste basicamente de proteína dietética não degradada no rúmen e de proteína microbiana. Antes do completo desenvolvimento ruminal, observa-se uma redução no desempenho animal, justificado pela menor capacidade de ingestão de alimentos sólidos e reduzida digestibilidade dos nutrientes. 
De modo geral, o pior desempenho dos animais, a redução na digestibilidade dos nutrientes e a menor retenção de nitrogênio obtidos com a substituição das proteínas lácteas da dieta, estão associados ao aumento da excreção fecal e dos escores fecais (Huber e Campos, 1982). A utilização de proteínas da soja ou proteínas de peixes em substituição as proteínas lácteas, em diversos níveis, levou ao aumento dos escores fecais e a redução no teor de matéria seca das fezes que na maioria das vezes resultou na ocorrência de diarréias, principalmente entre a $2^{\mathrm{a}}$ e a $4^{\mathrm{a}}$ semana de vida, demonstrando ser essa fase de maior sensibilidade dos bezerros as proteínas não lácteas.

As diarréias podem ser resultantes da incapacidade de formação de coágulo no abomaso ocorrendo a rápida passagem da fração protéica através do trato digestivo, diminuindo a digestibilidade da proteína e retenção de nitrogênio pelo bezerro e aumentando a atividade bacteriana no trato intestinal (Caughant et al., 1994). 


\section{MATERIAL E MÉTODOS}

\subsection{Animais e instalações experimentais}

O trabalho experimental foi realizado na Fazenda Pinhalzinho, localizada na cidade de Araras, SP, no periodo de abril de 1998 a fevereiro de 1999.

Foram utilizados 96 bezerros e bezerras da raça Holandesa, sendo 48 machos e 48 fêmeas. O período experimental foi do nascimento até os 120 dias de vida.

Os animais foram mantidos na coleira com correntes, em um bezerreiro com piso de madeira (ripado) elevado a uma altura média de $1 \mathrm{~m}$ e alojados em baias individuais providas de comedouros individuais e de bebedouros automáticos para cada dois bezerros. As laterais Norte-Sul eram bem abertas permitindo uma excelente ventilação.

\subsection{Tratamentos}

De acordo com o nascimento, os animais foram dispostos num arranjo fatorial $2 \times 4$, correspondendo a leite integral ou sucedâneo e a quatro tipos do processamento do milho: milho moído fino no pelete, milho floculado $283 \mathrm{~g} / \mathrm{L}$, 
milho floculado $360 \mathrm{~g} / \mathrm{L}$ e milho floculado $437 \mathrm{~g} / \mathrm{L}$. Os animais foram distribuídos em blocos ao acaso, em função do sexo e data de nascimento sendo o peso aos 15 dias utilizado como covariável.

O concentrado utilizado neste experimento foi o da marca comercial "Soylac Rúmen $18 \%$ ", e se apresentava na forma peletizada onde o milho floculado nas diferentes densidades não estava incorporado ao pelete. Para o tratamento com milho moído fino, utilizou-se uma formulação comercial onde o milho estava todo incorporado no pelete, porém continha $35 \%$ de milho. A Tabela 1 mostra a composição básica do concentrado contendo milho floculado.

Tabela 1. Composição do concentrado contendo milho floculado.

\begin{tabular}{lc}
\hline Ingredientes & Percentagem \\
\hline Milho & 51,0 \\
Farelo de soja & 18,0 \\
Farelo de trigo & 18,0 \\
Soja grão tostada & 5,0 \\
Premix vitamínico e mineral & 1,0 \\
Farelo de glúten de milho & 2,0 \\
Melaço & 3,0 \\
Calcáreo & 1,5 \\
Sal comum & 0,5 \\
\hline
\end{tabular}

As amostras dos concentrados, sucedâneo e silagem de milho foram enviadas a um laboratório onde foi feita a análise mineral (Tabela 2). 
Tabela 2. Análise mineral dos concentrados, sucedâneo e silagem de milho.

\begin{tabular}{lccc}
\hline Mineral & Concentrados & Sucedâneo & Silagem de milho \\
\hline Cálcio (\%) & 1,36 & 0,93 & 0,26 \\
Fósforo (\%) & 0,82 & 0,64 & 0,12 \\
Nitrogênio (\%) & 3,08 & 4,13 & 1,31 \\
Potássio (\%) & 1,04 & 1,44 & 0,84 \\
Magnésio (\%) & 0,33 & 0,17 & 0,16 \\
Enxofre (\%) & 0,22 & 0,20 & 0,10 \\
Sódio (ppm) & 280,0 & 800,0 & 160,0 \\
Cobre (ppm) & 29,0 & 10,0 & 4,0 \\
Ferro (ppm) & 630,0 & 103,0 & 370,0 \\
Manganês (ppm) & 134,0 & 27,0 & 29,0 \\
Zinco (ppm) & 138,0 & 53,0 & 16,0 \\
Cobalto (ppm) & 0,36 & 0,42 & 0,05 \\
\hline
\end{tabular}

O leite utilizado fresco e sem nenhum processamento era composto por um "pool" de leite de animais da primeira semana de lactação, proveniente do sistema de produção da Fazenda Pinhalzinho. O sucedâneo da marca comercial "Milkolac" continha os seguintes ingredientes básicos: soro de leite em pó, concentrado protéico de soro de leite (WPC), caseína, gordura animal estabilizada, premix mineral e vitamínico e concentrado protéico vegetal.

As análises bromatológicas dos concentrados, silagem de milho, sucedâneo e leite foram realizadas no Laboratório de Bromatologia do Departamento de Produção Animal ESALQ/USP e estão apresentados na Tabela 3. 
Tabela 3. Composição dos alimentos em porcentagem da MS.

\begin{tabular}{lrrrrrrrr}
\hline \multicolumn{7}{c}{ DIETAS $^{2}$} \\
\hline Nutrientes & 1 & MMF & $\mathbf{2 8 3}$ g/L & $\mathbf{3 6 0}$ g/L & $\mathbf{4 3 7}$ g/L & Sil. milho & Suced. & Leite \\
\hline MS \% & 93,19 & 92,71 & 92,81 & 92,70 & 33,68 & 94,44 & 14,15 \\
MM \% & 12,52 & 11,17 & 10,78 & 10,83 & 4,27 & 7,47 & 5,86 \\
EE \% & 3,80 & 3,80 & 3,48 & 3,61 & 2,82 & 16,78 & 29,15 \\
FDN \% & 32,30 & 29,31 & 28,61 & 29,59 & 42,86 & 6,65 & - \\
FDA \% & 11,53 & 10,76 & 10,74 & 11,33 & 25,39 & 4,64 & - \\
FB\% & 7,81 & 7,23 & 7,18 & 7,61 & 21,8 & 2,50 & \\
PB \% & 18,98 & 18,64 & 18,50 & 18,23 & 8,22 & 25,81 & 27,33 \\
Amido \% & 20,63 & 28,41 & 28,79 & 27,45 & 28,20 & 15,61 & \\
NDT\% & 71,3 & 72,5 & 72,4 & 72,3 & 62,2 & 84,95 & \\
\hline
\end{tabular}

Nutrientes: $M S$ = matéria seca; $M M=$ matéria mineral; $E E=$ extrato etéreo; $F D N=$ fibra em detergente neutro; $F D A=$ fibra em detergente ácido; $F B=$ fibra bruta; $P B=$ proteína bruta; $N D T$ = nutrientes digestiveis totais, calculado de acordo com Kearl (1982).

2 Dietas: $M M F=$ milho moido fino; $283 \mathrm{~g} / \mathrm{L}=$ milho floculado $283 \mathrm{~g} / \mathrm{L} ; 360 \mathrm{~g} / \mathrm{L}=$ milho floculado $360 \mathrm{~g} / \mathrm{L} ;$ $437 \mathrm{~g} / \mathrm{L}=$ milho floculado $437 \mathrm{~g} / \mathrm{L} ;$ Sil. milho = silagem de milho; Suced. = sucedâneo .

\subsection{Alimentação e manejo dos animais}

Após o nascimento, os animais foram separados das mães, pesados, identificados e alojados em baias individuais onde receberam em torno de $5 \%$ do peso vivo de colostro a cada 12 horas até o segundo dia de vida, com a utilização de mamadeira. Os animais que apresentaram dificuldade em mamar, receberam o colostro através de sonda esofágica. Ao primeiro, $15^{\circ}$ e $30^{\circ}$ dia de vida os animais foram vacinados contra pasteurelose e salmonelose e no $1^{\circ}$ dia contra colibacilose.

Após o terceiro dia, os animais passaram a receber quatro litros de leite divididos em dois horários: 7 horas e as 16 horas. Já os animais que faziam 
parte do tratamento com sucedâneo passaram a recebê-lo a partir do $15^{\circ}$ dia de vida. Esse manejo foi adotado devido a um pré-ensaio realizado com alguns animais, onde o sucedâneo foi fornecido a partir do terceiro dia de vida do animal e observou-se que estes apresentavam grande perda de peso e uma dificuldade em retornar ao ganho de peso normal. O sucedâneo era preparado diariamente, antes de cada refeição, misturando-se $200 \mathrm{~g}$ do produto em água pré-aquecida para cada 2 litros de sucedâneo reconstituído.

A água foi fornecida ad libitum desde os primeiros dias de vida. $O$ concentrado também foi fornecido desde o primeiro dia de vida, em pequenas quantidades aumentando-se de acordo com o consumo. Quando o consumo de concentrado atingia $800 \mathrm{~g} / \mathrm{dia}$, durante três dias consecutivos, os animais eram desmamados bruscamente e pesados (Campos \& Lizieire, 1998). A partir da desmama, o concentrado continuava a ser fornecido em quantidades crescentes, de acordo com o consumo, até o animal atingir $2,5 \mathrm{~kg} / \mathrm{dia}$, sendo esta quantidade fixada e a demanda da necessidade energética com o crescimento do animal foi compensada com o fornecimento ad libitum, diário, de silagem de milho até os 120 dias de vida do animal, ou seja, final do experimento.

\subsection{Colheita de dados e de amostras}

O fornecimento de concentrado e de silagem de milho foi registrado diariamente, assim como as sobras da silagem de milho, enquanto que a sobra do concentrado foi pesada semanalmente. Esses dados foram utilizados para a análise do consumo de matéria seca diária, que foi obtida através da diferença entre a quantidade de matéria seca fornecida e a da sobra.

Foram registrados os pesos dos animais ao nascimento, semanalmente, à desmama e ao final da fase experimental (120 dias de vida). A idade à 
desmama e ao início de consumo de silagem de milho também foram registrados.

As amostras dos concentrados, da silagem de milho e do sucedâneo foram coletadas semanalmente, enquanto que amostras do leite fornecido aos animais, foram colhidas diariamente. Todas as amostras foram mantidas a $-10^{\circ} \mathrm{C}$ para posterior análise bromatológica (matéria seca, proteína bruta, fibra bruta, fibra em detergente neutro, fibra em detergente ácido, matéria mineral e extrato etéreo).

\subsection{Processamento do grão de milho}

No tratamento milho moido fino, o milho foi todo incorporado ao pelete $(35 \%)$, entretanto nos outros tratamentos, além do milho floculado presente no concentrado, havia uma pequena quantidade de milho moido incluído no pelete $(5 \%)$, de modo que foi mantida sempre a mesma quantidade de milho floculado nos concentrados (46\%). Para obtenção do milho floculado, o grão foi exposto ao vapor por 30 minutos, à temperatura de $90^{\circ} \mathrm{C}$. O grão de milho quente e úmido, passava entre rolos ajustáveis para a obtenção do floco. A distância desses rolos determinava a densidade do floco $(283,360$ ou $437 \mathrm{~g} / \mathrm{L})$.

\subsection{Análises bromatológicas}

As amostras de silagem de milho foram secas em estufas de ventilação forçada $\left(55-60^{\circ} \mathrm{C}\right)$ por 72 horas para determinação de MS, de acordo com A.O.A.C. (1990). As amostras dos concentrados e da silagem de milho présecada foram moídas em moinhos tipo Willey providos de peneira de malha de 
$1 \mathrm{~mm}$ de diâmetro e acondicionadas em potes plásticos devidamente identificados.

As amostras de silagem de milho, concentrados e do sucedâneo foram analisadas para matéria seca $\left(105^{\circ} \mathrm{C}\right)$, matéria mineral, proteína bruta e fibra bruta de acordo com A.O.A.C. (1990), e a fibra em detergente neutro (FDN) e fibra em detergente ácido (FDA) de acordo com Van Soest et al. (1991). Nas amostras dos concentrados e da silagem de milho foram feitas a determinação do amido e a taxa de hidrólise in vitro do amido de acordo com Poore et. al (1989).

As amostras do leite foram compostas por mês e liofilizadas (Labconco Lyph-Lock® 6 Liter Freeze System), até atingirem peso constante (72 horas), para obtenção do extrato seco do leite integral e determinação da MS. O extrato seco foi analisado para matéria mineral, proteína bruta e extrato etéreo, pelas metodologias mencionadas anteriormente.

\subsection{Análise estatística}

O delineamento experimental utilizado foi o de blocos casualizados de acordo com sexo e data de nascimento, com 12 repetições, em um arranjo fatorial $2 \times 4$ (tipo de dieta líquida $x$ tipo de processamento do milho).

Os dados foram analisados através do procedimento "General Linear Model" (PROC GLM) do programa estatístico SAS (1991). A variável ganho de peso foi obtida em função da inclinação da curva através de regressão linear simples, entre o peso do animal e idade. Todos os dados foram submetidos à análise de variância que separou como causas de variação o efeito do tipo de dieta líquida (leite ou sucedâneo), efeito do processamento do milho, efeito da interação dieta líquida $X$ processamento do milho, efeito de bloco e efeito da covariável peso aos 15 dias. Nos casos em que houve interação, os efeitos do 
processamento de milho foram analisados dentro de cada tipo de dieta líquida, onde foram separados por contrastes ortogonais, separando o efeito do milho moído fino vs. floculados e entre os floculados. Para todas essas análises, utilizou-se o nivel de significância de $5 \%$.

Tabela 4. Esquema da análise de variância.

\begin{tabular}{lc}
\hline \multicolumn{1}{c}{ Causas de Variação } & Grau de Liberdade \\
\hline Processamento do milho & 3 \\
Dieta líquida & 1 \\
Interação (dieta líquida x processamento) & 3 \\
Bloco & 11 \\
Peso vivo aos 15 dias de vida & 1 \\
Resíduo & 76 \\
\hline TOTAL & 95 \\
\hline
\end{tabular}




\section{RESULTADOS E DISCUSSÃO}

\subsection{Taxa de Hidrólise}

A Figura 1 mostra as taxas de hidrólise in vitro dos concentrados com milho floculado e do milho moído fino no pelete. A taxa de hidrólise in vitro do amido com milho floculado diminuiu com o aumento da densidade dos grãos, conforme reportado na literatura (Zinn, 1990a; Swingle, 1993; Chen et al., 1994 e Plascencia \& Zinn, 1996). Esse fato demonstra a relação entre a diminuição da densidade e o aumento da disponibilidade do amido (Swingle, 1993). Entretanto, a taxa de hidrólise do floculado $360 \mathrm{~g} / \mathrm{L}$ e do milho moído fino não foram diferentes. Os valores da taxa de hidrólise do floculado de densidade 360 $\mathrm{g} / \mathrm{L}$ foi superior ao encontrado por Yu et al. (1998), o que pode ter sido causado pelo processamento mais intenso para o milho utilizado neste trabalho.

O milho moído fino (MMF) apresentou maior taxa de hidrólise (80\%) quando comparado ao $437 \mathrm{~g} / \mathrm{L}(76 \%)$, revelando que o milho moído fino foi mais intensamente processado durante a peletização do que o milho floculado a $437 \mathrm{~g} / \mathrm{L}$. 


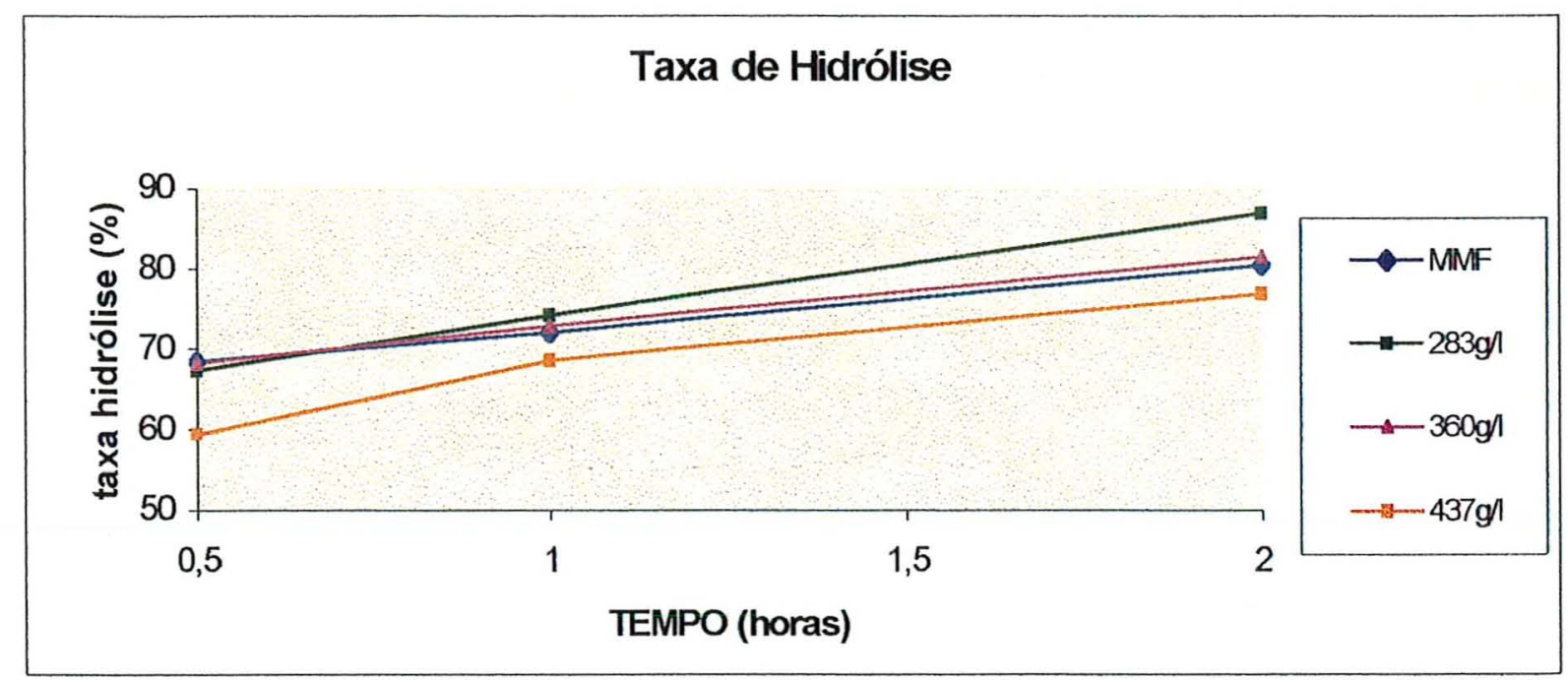

MMF= milho moído fino; $283 \mathrm{~g} / \mathrm{L}=$ milho floculado $283 \mathrm{~g} / \mathrm{L} ; 360 \mathrm{~g} / \mathrm{L}=$ milho floculado $360 \mathrm{~g} / \mathrm{L} ; 437 \mathrm{~g} / \mathrm{L}=\mathrm{milho}$ floculado $437 \mathrm{~g} / \mathrm{L}$.

Figura 1. Taxa de hidrólise "in vitro" do amido dos concentrados.

\subsection{Desempenho dos 15 dias à desmama}

\subsubsection{Consumo diário do concentrado}

O consumo de concentrado com base na matéria seca, dos 15 dias à desmama, não foi afetado pelo processamento do milho, tipo de dieta líquida assim como não ocorreu interação entre os efeitos principais (Tabelas 5 e 6).

Silva et al. (1987), estudando os efeitos do leite e de um sucedâneo, em diferentes idades de desmama (21, 28 e 35 dias), em bezerros da raça Holandesa, verificaram que os animais que receberam sucedâneo consumiram mais concentrado do que aqueles que receberam leite. Eles verificaram que o consumo de concentrado dos animais tratados com sucedâneo foi em média $0,344 \mathrm{~kg} / \mathrm{dia}$, semelhante aos resultados encontrados neste trabalho (Tabela 5), entretanto, os animais do grupo que recebeu leite consumiram $0,184 \mathrm{~kg} / \mathrm{dia}$ do concentrado oferecido, enquanto neste trabalho, o consumo foi de $0,35 \mathrm{~kg} / \mathrm{dia}$. Já, Abrahão (1980) e Vasconcelos et al. (1998) observaram menor consumo de concentrado em bezerros que receberam o sucedâneo, comparados aos que 
receberam leite. Matos et al. (1984) estudaram três marcas comerciais de sucedâneos e verificaram que em dois sucedâneos, os animais consumiram mais concentrado do que aqueles que receberam leite, enquanto que com o terceiro sucedâneo o consumo foi igual. Esses resultados demonstraram que há variabilidade no consumo de concentrado entre os diversos tipos de sucedâneos, sendo que a baixa qualidade da proteína e balanço de aminoácidos na composição do sucedâneo podem afetar o consumo (Kertz et al., 1979).

O consumo de concentrado contendo sorgo laminado ou floculado, observado por Shuh et al. (1970), do nascimento até a desmama (35 dias) foi de $0,285 \mathrm{~kg} / \mathrm{dia}$, enquanto a média deste experimento foi de $0,34 \mathrm{~kg} / \mathrm{dia}$. Em outro trabalho, Shuh et al. (1971) observaram um consumo ainda menor de concentrado contendo grão de sorgo floculado $(0,22 \mathrm{~kg} / \mathrm{dia})$. O menor consumo encontrado nesses trabalhos, deve ser devido ao fato de que os dados de consumo de concentrado analisados no presente estudo foram a partir da terceira semana de vida dos animais, considerando também, que nessas duas primeiras semanas o consumo de alimento sólido é muito reduzido. 
Tabela 5. Efeitos do processamento do milho e tipo de dieta líquida sobre o desempenho dos(as) bezerros(as) na pré-desmama (dados corrigidos pela covariável peso aos 15 dias).

\begin{tabular}{|c|c|c|c|c|c|c|c|c|c|c|}
\hline \multirow[t]{2}{*}{ Parâmetro } & \multicolumn{2}{|c|}{ Dieta líquida } & \multicolumn{4}{|c|}{ Processamento do milho $^{1}$} & \multirow[b]{2}{*}{ Média } & \multirow[b]{2}{*}{$\mathrm{EPM}^{4}$} & \multicolumn{2}{|c|}{$\mathbf{P}^{2}$} \\
\hline & Leite & Suced. $^{3}$ & MMF & 283 & 360 & 437 & & & D. Liq. & Proc. \\
\hline \multicolumn{11}{|c|}{ Consumo de MS (kg/dia) ${ }^{5}$} \\
\hline Concentrado & 0,35 & 0,34 & 0,32 & 0,38 & 0,34 & 0,33 & 0,34 & 0,013 & NS & NS \\
\hline Total & 0,83 & 0,68 & 0,76 & 0,75 & 0,76 & 0,75 & 0,75 & 0,012 & 0,0001 & NS \\
\hline Peso inicial ${ }^{6}$ & 42,5 & 41,8 & 42,9 & 41,7 & 42,5 & 41,5 & 42,2 & - & - & - \\
\hline $\mathrm{GP}(\mathrm{kg} / \mathrm{dia})^{7}$ & 0,55 & 0,29 & 0,39 & 0,42 & 0,47 & 0,41 & 0,42 & 0,020 & 0,0001 & NS \\
\hline$C A^{8}$ & 1,63 & 2,5 & 2,17 & 2,20 & 2,04 & 2,02 & 2,11 & 0,105 & 0,0001 & NS \\
\hline$P D(k g)^{9}$ & 63,3 & 52,5 & 57,8 & 57,9 & 59,1 & 56,7 & 57,9 & 0,856 & 0,0001 & NS \\
\hline ID (dias) $^{10}$ & 55,5 & 51,9 & 56,9 & 52,0 & 53,4 & 52,7 & 53,7 & 1,370 & NS & NS \\
\hline
\end{tabular}


Tabela 6. Interação entre processamento do milho e tipo de dieta líquida sobre o desempenho dos(as) bezerros(as) na pré-desmama (dados corrigidos pela covariável peso aos 15 dias)

\begin{tabular}{|c|c|c|c|c|c|c|c|c|c|c|c|c|c|c|}
\hline \multirow[t]{2}{*}{ Parâmetro } & \multicolumn{3}{|c|}{ Leite } & \multicolumn{5}{|c|}{ Sucedâneo } & \multirow[b]{2}{*}{$E P M^{5}$} & \multirow[b]{2}{*}{$\mathrm{PxL}^{6}$} & \multicolumn{2}{|c|}{$P(L)^{7}$} & \multicolumn{2}{|c|}{$\mathbf{P}(\mathbf{S})^{8}$} \\
\hline & MMF $^{1}$ & $283^{2}$ & $360^{3}$ & $437^{4}$ & MMF & 283 & 360 & $\overline{437}$ & & & $\mathrm{MxF}$ & Floc & MxF & Floc \\
\hline \multicolumn{15}{|c|}{ Consumo de MS (kg/dia) } \\
\hline Conc. & 0,31 & 0,38 & 0,36 & 0,34 & 0,32 & 0,39 & 0,33 & 0,31 & 0,013 & NS & NS & NS & NS & NS \\
\hline Total & 0,63 & 0,84 & 0,82 & 0,82 & 0,68 & 0,67 & 0,69 & 0,67 & 0,012 & NS & NS & NS & NS & NS \\
\hline Peso inicial ${ }^{10}$ & 43,2 & 41,6 & 43,2 & 41,8 & 41,6 & 41,7 & 41,9 & 41,2 & - & - & - & - & - & - \\
\hline $\mathrm{GP}(\mathrm{kg} / \mathrm{dia})^{11}$ & 0,51 & 0,55 & 0,62 & 0,51 & 0,27 & 0,30 & 0,31 & 0,30 & 0,020 & NS & NS & NS & NS & NS \\
\hline$C A^{12}$ & 1,68 & 1,56 & 1,63 & 1,64 & 2,66 & 2,83 & 2,46 & 2,40 & 0,105 & NS & NS & NS & NS & NS \\
\hline $\mathrm{PD}(\mathrm{kg})^{13}$ & 61,8 & 64,8 & 65,9 & 60,2 & 53,9 & 51,0 & 52,4 & 52,5 & 0,856 & NS & NS & NS & NS & NS \\
\hline ID (dias) $^{14}$ & 53,2 & 58,1 & 57,2 & 53,4 & 60,5 & 45,9 & 49,6 & 51,6 & 1,370 & 0,0425 & NS & NS & 0,0026 & NS \\
\hline
\end{tabular}




\subsubsection{Consumo diário de matéria seca total (MS)}

O processamento do milho não teve efeito significativo no consumo de MS total dos 15 dias à desmama. Entretanto, os animais tratados com sucedâneo consumiram menos matéria seca $(0,68 \mathrm{~kg} / \mathrm{dia})$ que os tratados com leite $(0,83 \mathrm{~kg} / \mathrm{dia} ; \mathrm{P}<0,05)$. Este menor consumo de $\mathrm{MS}$ apresentado pelos bezerros que receberam sucedâneo (Tabela 5 ), pode ser atribuído a menor quantidade de MS no sucedâneo do que no leite. Considerando o consumo de 4 litros por dia da dieta líquida, sendo que a matéria seca do leite era de $14,15 \%$ e do sucedâneo reconstituído de $9,4 \%$ (100g do sucedâneo diluído em $900 \mathrm{ml}$ de água), verificou-se que os animais do sucedâneo consumiram diariamente $378 \mathrm{~g}$ de MS/dia, enquanto que aqueles que receberam leite consumiram $566 \mathrm{~g}$ de MS/dia. Apesar da diferença no consumo de MS da dieta líquida ser de $33 \%$ (Tabela 3), observa-se que a diferença no consumo de MS total (leite e concentrado), foi de apenas $17 \%$, esse fato pode ser devido ao consumo semelhante de concentrado entre os dois tratamentos (Tabela 5). Também não houve efeito de interação entre o tipo de dieta líquida e o processamento do milho (Tabela 6)

Banys et al. (1998) não encontraram diferença sobre o consumo de MS total dos bezerros que receberam sucedâneo a base de proteína texturizada de soja com diferentes fontes de lactose (pura, soro de queijo em pó ou leite em pó desnatado) em relação aos que receberam leite, dos 7 dias de vida até a desmama.

\subsubsection{Ganho de peso}

O processamento do milho não afetou o ganho de peso dos animais, do mesmo modo não houve efeito de interação entre o tipo de dieta líquida e o processamento do milho (Tabela 6). Entretanto, o tipo de dieta líquida afetou significativamente $(P<0,05) \circ$ ganho de peso dos 15 dias até a desmama. Os 
animais que receberam sucedâneo como dieta líquida apresentaram ganho de peso $47,2 \%$ menor do que os animais que receberam leite $(0,29 \mathrm{vs.} 0,55 \mathrm{~kg} / \mathrm{dia}$; Tabela 5).

Resultados semelhantes ao presente trabalho foram registrados por Silva et al. (1987) e Alves et al. (1997). Esses autores observaram maiores ganhos de peso para os animais que receberam leite quando comparados ao sucedâneo de marca comercial, visto que Silva et al. (1987) também forneceram sucedâneo com quantidade de matéria seca inferior ao do leite para os bezerros. Silva et al. (1986) observaram maiores ganhos de peso em animais que receberam sucedâneo com proteína de soja, comparados com bezerros que receberam sucedâneo com apenas proteína do leite. Vasconcelos et al. (1998), forneceram leite ou sucedâneo para bezerros do nascimento até a oitava semana de vida e observaram que não houve diferença para o ganho de peso entre os dois tratamentos apesar do ganho de peso com sucedâneo ter sido menor $(0,34$ e $0,30 \mathrm{~kg} / \mathrm{dia}$, leite e sucedâneo, respectivamente). Observouse que o ganho de peso dos animais tratados com sucedâneo nesse experimento foi similar enquanto que o do leite foi superior ao encontrado pelos autores citados (Tabela 5). O ganho de peso médio dos animais tratados com leite até a desmama $(0,55 \mathrm{~kg} / \mathrm{dia})$, também foi superior ao encontrado por Carvalho et al. (1983). Ao desmamar os bezerros quando consumiam $800 \mathrm{~g} / \mathrm{dia}$ de concentrado, os autores observaram ganhos de 0,321 kg/dia. Essa diferença de ganho, comparada ao presente trabalho, pode ter sido devido ao tipo de dieta sólida oferecida aos animais, que não foi mencionada pelos autores, o que prejudicou a comparação dos dados. Já o ganho de peso e o peso a desmama encontrados por Winter (1985) foram similares aos encontrados neste estudo.

Matos et al. (1984) ao estudarem os efeito de três marcas de sucedâneos verificaram que os animais que receberam leite ganharam 0,43 $\mathrm{kg} /$ dia sendo esse resultado menor do que o encontrado neste estudo $(0,55$ $\mathrm{kg} / \mathrm{dia}$ ), enquanto que em dois dos três tipos de sucedâneos estudados, os ganhos de peso foram superiores $(0,42$ e $0,40 \mathrm{~kg} / \mathrm{dia}$ vs. $0,29 \mathrm{~kg} / \mathrm{dia})$. No 
entanto, a terceira marca mostrou menor desempenho $(0,23 \mathrm{~kg} / \mathrm{dia})$. demonstrando novamente, variabilidade nas respostas de diferentes sucedâneos, como também de concentrado para bezerros que devem apresentar boa palatabilidade para ser consumido pelos animais.

Lucci (1989) sugeriu que o ganho médio, para bezerros em aleitamento até os três meses de vida, deveria estar entre 0,4 e $0,5 \mathrm{~g} / \mathrm{dia}$. Os animais deste estudo alimentados com sucedâneo tiveram ganho de peso inferior $(0,30$ $\mathrm{kg} / \mathrm{dia})$, enquanto que para aqueles que consumiram leite $(0,55 \mathrm{~kg} / \mathrm{dia}) \circ \mathrm{ganho}$ de peso diário está de acordo com o proposto pelo autor. Essas respostas também estão de acordo com Faria \& Ghelfi (1993), que sugeriram ganhos de pesos de $550 \mathrm{~g} /$ dia até os 2 meses de idade para o crescimento ideal de fêmeas, visando atingir parição aos 24 meses.

A perda de peso durante a primeira ou segunda semana de vida é freqüentemente observada em bezerros alimentados com sucedâneo (Jaster et al., 1990). Segundo Abrahão (1980), bezerros alimentados com sucedâneo, apresentam ganhos de peso similares aos que recebem leite a partir da quarta semana de vida, fato este que não ocorreu neste experimento, uma vez que os animais começaram a receber o sucedâneo a partir da terceira semana de vida e apresentaram ganhos de peso inferiores aos tratados com leite, e em algumas comparações com outros estudos, esses ganhos de peso foram ainda menores, apesar do consumo de concentrado não ter diferido.

Segundo Fisher (1976), os sucedâneos comerciais quando fornecidos para bezerros, apresentam baixa quantidade de matéria seca e baixa digestibilidade de seus constituintes nutricionais, proporcionando eficiência alimentar e ganho de peso menores, quando comparados com os do leite devido à baixa quantidade de proteína láctea e alta de proteína vegetal. No sucedâneo utilizado no presente experimento, parte da proteína láctea foi substiuida pela proteína de soja, a qual em bezerros não é eficientemente utilizada, provavelmente devido a redução na secreção de enzimas 
pancreáticas e na dificuldade da proteína da soja em coagular no abomaso (Thernouth et al., 1975).

As médias do ganho de peso em relação aos concentrados (Tabela 5) foram maiores do que as encontradas por Shuh et al. (1970) e Shuh et al. (1971), que estudaram os efeitos do sorgo floculado $(0,23$ e $0,29 \mathrm{~kg} / \mathrm{dia}$, respectivamente).

\subsubsection{Conversão alimentar (CA)}

O processamento do milho não interferiu na conversão alimentar dos 15 dias de vida até a desmama e também não foi observado interação entre o processamento do milho e o tipo de dieta líquida. Já o tipo da dieta líquida teve efeito significativo $(\mathrm{P}<0,05)$ sobre a $\mathrm{CA}$ dos 15 dias à desmama. Os animais que receberam o sucedâneo apresentaram pior CA $(2,5)$ que os animais do tratamento com leite $(1,63$; Tabela 5$)$. Embora os animais do tratamento com sucedâneo terem apresentado menor consumo de matéria seca em relação aos do tratamento com leite, a diminuição de ganho de peso, como discutido anteriormente, ainda resultou numa piora da CA.

Independentemente do tipo de processamento do milho, as CA dos 15 dias até a desmama foram maiores que as encontradas por Winter (1985), que observou em bezerros que recebiam leite e foram desmamados nas $3^{\mathrm{a}}, 5^{\mathrm{a}}$ e $7^{\mathrm{a}}$ semanas, CA iguais a $2,04,1,56$ e 1,33 , respectivamente.

Analisando apenas os tratamentos contendo o milho floculado (Tabela 5), verificou-se que as CA também foram maiores que as encontradas por Shuh et al. (1970), onde bezerros que receberam sorgo floculado ou laminado, apresentaram CA iguais a 1,37 e 1,13 respectivamente, para os animais desmamados aos 35 dias e de 1,53 e 1,26 quando desmamados aos 24 dias de vida. 


\subsubsection{Peso vivo à desmama}

Foi observado apenas efeito da dieta líquida no peso vivo à desmama $(P<0,05)$, sendo que o processamento do milho e a interação entre os dois fatores não foram significativos (Tabelas 5 e 6). Devido ao fato dos animais tratados com sucedâneo terem ganho diariamente menos peso, foram os que apresentaram o menor peso na desmama $(52,5 \mathrm{~kg})$ em relação aos aleitados com leite $(63,3 \mathrm{~kg}$; Tabela 5). Esse fato pode ser atribuído à menor quantidade de MS no sucedâneo reconstituído comparado ao leite ( $378 \mathrm{~g} / \mathrm{dia}$ vs. $566 \mathrm{~g} / \mathrm{dia}$ ).

Campos \& Liziere (1998) sugeriram que o peso vivo à desmama para fêmeas da raça Holandesa com 2 meses de idade, visando alcançar a parição aos 24 meses de vida, seja de $68 \mathrm{~kg}$. Neste caso, a média de peso vivo dos animais tratados com sucedâneo $(52,5 \mathrm{~kg})$ está abaixo do proposto pelos autores, uma vez que a média da idade também foi de aproximadamente dois meses (51,9 dias; Tabela 5). Entretanto, observou-se que a média do tratamento com leite $(63,3 \mathrm{~kg})$ está ligeiramente abaixo do proposto por esses autores, mas está de acordo com o sugerido por Davis \& Drakley (1998), para as 9 semanas de vida ( 65 a $75 \mathrm{~kg}$ ), considerando que os animais ganhariam $0,55 \mathrm{~kg} / \mathrm{dia}$ até atingirem 9 semanas de idade.

\subsubsection{Idade à desmama}

O fornecimento do milho processado e o tipo de dieta líquida não afetaram a idade à desmama (Tabela 5). Entretanto houve interação entre esses dois fatores $(P<0,05)$. Entre os animais que receberam leite não houve diferença (Tabela 6) para o tipo de concentrado, no entanto, animais que receberam o sucedâneo e o concentrado com milho moído fino foram desmamados mais tarde (60,5 dias) quando comparados aos outros animais da mesma dieta líquida e que receberam milho floculado $(P<0,05$; Tabela 6$)$. Observou-se também que os animais tratados com leite e que receberam 
concentrado com milho moído fino foram desmamados mais precocemente (53,2 dias). Apesar de não significativo, os animais que receberam sucedâneo foram desmamados em média 4 dias mais cedo do que aqueles que receberam leite (Tabela 5).

Bush \& Nicholson (1986), estudando os efeitos do tipo de desmama em bezerras da raça Holandesa verificaram que a idade média de bezerras desmamadas bruscamente, após consumirem $1000 \mathrm{~g}$ de ração inicial foi de 54,5 dias. Essas respostas são similares as encontradas no presente trabalho, considerando que a média geral de todos os tratamentos foi de 53,7 dias, porém os animais foram desmamados após consumirem $800 \mathrm{~g} / \mathrm{dia}$ de concentrado. Em geral, a idade a desmama encontrada neste trabalho está dentro da sugerida por Campos e Liziere (1998), que acreditam não haver necessidade de se fornecer dieta líquida além da oitava semana de vida.

\subsection{Desempenho da desmama ao final do experimento (120 dias)}

\subsubsection{Consumo de matéria seca total (MS)}

O consumo de MS da desmama aos 120 dias de idade incluiu a MS do concentrado e da silagem de milho. O processamento do milho não afetou o consumo de matéria seca da desmama ao final do experimento (Tabela 7). Entretanto, quando se comparou somente o tipo de dieta líquida ocorreu uma diminuição no consumo de MS pelos animais tratados com sucedâneo $(P<0,05$; Tabela 7). Este menor consumo pode ter sido devido ao menor peso vivo a desmama dos animais tratados com sucedâneo. Em contraste com o obtido neste experimento, Banys et al. (1998), Matos et al. (1984) e Silva et al. (1987), não observaram diferenças entre o tipo de dieta líquida sobre o consumo de MS após a desmama. 
Shuh et al. (1971) observaram que bezerros desmamados aos 41dias de idade consumiram em média $2,30 \mathrm{~kg}$ de MS/dia de sorgo floculado e feno, dos 41 dias até os 90 dias de idade, valor este que está um pouco abaixo do consumo encontrado neste estudo $(2,60 \mathrm{~kg}$ de MS/dia). 
Tabela 7. Efeitos do processamento do milho e tipo de dieta líquida sobre o desempenho dos(as) bezerros(as) após a desmama (dados corrigidos pela covariável peso aos 15 dias).

\begin{tabular}{|c|c|c|c|c|c|c|c|c|c|c|}
\hline \multirow[t]{2}{*}{ Parâmetro } & \multicolumn{2}{|c|}{ Dieta líquida } & \multicolumn{4}{|c|}{ Processamento ${ }^{1}$} & \multirow[b]{2}{*}{ Média } & \multirow[b]{2}{*}{$\mathrm{EPM}^{4}$} & \multicolumn{2}{|c|}{$\mathbf{P}^{2}$} \\
\hline & Leite & Suced. $^{3}$ & MMF & 283 & 360 & 437 & & & D. Liq. & Proc. \\
\hline $\mathrm{CMS}(\mathrm{kg} / \mathrm{dia})^{5}$ & 2,71 & 2,50 & 2,48 & 2,62 & 2,55 & 2,75 & 2,60 & 0,039 & 0,0027 & NS \\
\hline Peso inicial ${ }^{6}$ & 42,5 & 41,9 & 42,9 & 41,7 & 42,5 & 41,5 & 42,5 & - & $\begin{array}{ll}- \\
-\end{array}$ & - \\
\hline $\mathrm{GP}(\mathrm{kg} / \mathrm{dia})^{7}$ & 0,87 & 0,79 & 0,80 & 0,84 & 0,84 & 0,83 & 0,83 & 0,014 & 0,0025 & NS \\
\hline$C A^{8}$ & 3,12 & 3,28 & 3,26 & 3,16 & 3,10 & 3,28 & 3,20 & 0,066 & NS & NS \\
\hline IS (dias) ${ }^{9}$ & 66,0 & 70,7 & 73,1 & 67,3 & 67,8 & 65,0 & 68,3 & 1,47 & 0,0402 & NS \\
\hline
\end{tabular}

NS = năo significativo

1 = processamento do milho: MMF= milho moído fino; $283=$ floculado $283 \mathrm{~g} / ; 360=$ floculado $360 \mathrm{~g} / ; ; 437=$ floculado $437 \mathrm{~g} / ; 2=$ probabilidades: D. Liq. $=$ dieta liquida; proc $=$ processamento; $3=$ sucedâneo; $4=$ erro padrăo da média; $5=$ consumo de MS total (concentrado+silagem de milho); $6=$ peso vivo aos 15 dias de vida (covariável); 7 = ganho de peso médio diário; 8 = conversão alimentar (kgCMS/kgGP); 9 = idade ao início do consumo de silagem. 
Tabela 8. Interação entre processamento do milho e tipo de dieta líquida sobre o desempenho dos (as) bezerros (as) após a desmama (dados corrigidos pela covariável peso aos 15 dias).

\begin{tabular}{|c|c|c|c|c|c|c|c|c|c|c|c|c|c|c|}
\hline \multirow[t]{2}{*}{ Parâmetro } & \multicolumn{4}{|c|}{ Leite } & \multicolumn{4}{|c|}{ Sucedâneo } & \multirow[b]{2}{*}{$\mathrm{EPM}^{5}$} & \multirow[b]{2}{*}{$\mathrm{PXL}^{6}$} & \multicolumn{2}{|c|}{$P(L)^{7}$} & \multicolumn{2}{|c|}{$P(\mathbf{S})^{8}$} \\
\hline & $\mathrm{MMF}^{1}$ & $283^{2}$ & $360^{3}$ & $437^{4}$ & MMF & 283 & 360 & 437 & & & MxF & Floc & $\overline{M x F}$ & Floc \\
\hline${\mathrm{CMS}(\mathrm{kg} / \mathrm{dia})^{9}}^{9}$ & 92,66 & 2,77 & 2,60 & 2,79 & 2,30 & 2,48 & 2,51 & 2,71 & 0,039 & NS & NS & NS & NS & NS \\
\hline Peso inicial ${ }^{10}$ & 43,2 & 41,6 & 43,2 & 41,8 & 42,6 & 41,7 & 41,9 & 41,2 & - & - & - & - & - & - \\
\hline $\mathrm{GP}(\mathrm{kg} / \mathrm{dia})^{11}$ & 0,87 & 0,88 & 0,86 & 0,87 & 0,71 & 0,80 & 0,82 & 0,83 & 0,014 & NS & NS & NS & NS & NS \\
\hline$C A^{12}$ & 3,04 & 3,15 & 3,07 & 3,24 & 3,49 & 3,17 & 3,13 & 3,34 & 0,066 & NS & NS & NS & NS & NS \\
\hline IS $(\text { dias })^{13}$ & 66,4 & 66,9 & 67,1 & 63,4 & 79,8 & 67,7 & 68,6 & 66,5 & 1,470 & NS & NS & NS & NS & NS \\
\hline
\end{tabular}




\subsubsection{Ganho de peso}

Houve efeito significativo do tipo de dieta líquida no ganho de peso da desmama até o final do experimento $(P<0,05)$. Os animais tratados com sucedâneo tiveram ganho de peso inferior aos tratados com leite ( 0,79 vs. 0,87 kg/dia; Tabela 7) após a desmama. Esse ganho de peso menor pode ser reflexo do menor consumo de matéria seca que esses animais apresentaram após a desmama, como já visto anteriormente. Já o tipo de processamento do milho e sua interação com o tipo de dieta líquida não tiveram efeito sobre o ganho de peso.

Silva et al. (1987) não observaram diferenças no ganho de peso após a desmama ( 35 dias) até os 122 dias de vida, em bezerros que receberam leite ou sucedâneo comercial durante o período de aleitamento, entretanto, os animais que receberam sucedâneo ganharam numericamente mais peso do que os que receberam leite $(0,571$ e $0,664 \mathrm{~kg} / \mathrm{dia}$, leite e sucedâneo respectivamente), enquanto que no presente trabalho o maior ganho de peso foi nos animais que receberam leite. Segundo Lucci (1989), os ganhos de peso obtidos até o desmame não influenciam nos ganhos posteriores, exceto se ocorrer subalimentação. Pode-se observar este fato na Tabela 5 , onde se verifica que a diferença de ganho de peso entre os animais tratados com sucedâneo foi $47,2 \%$ menor que os tratados com leite durante o aleitamento, enquanto que após a desmama essa diferença diminuiu para 9,2\% (Tabela 7).

Ao observar a Tabela 8 , verifica-se que para os animais tratados com leite, a média dos ganhos de peso relacionados com o processamento do milho foi superior a apresentada por Shuh et al. (1971), que foi de $0,83 \mathrm{~kg} / \mathrm{dia}$ da desmama (41 dias) aos 90 dias de vida. Entretanto, ao observar aqueles que receberam o sucedâneo, e excluindo o concentrado contendo milho moído fino, percebe-se que as respostas são similares as encontradas por estes autores. 


\subsubsection{Conversão Alimentar (CA)}

Não houve efeito do processamento do milho, do tipo de dieta líquida nem interação entre esses fatores na CA da desmama ao final do período experimental (Tabelas 7 e 8). Como já discutido anteriormente, os animais tratados com sucedâneo ganharam menos peso em consequência do menor consumo de MS, não afetando a CA em comparação com aqueles que receberam leite, durante a fase pós-desmama.

Silva et al. (1987) verificaram melhores conversões alimentares para bezerros que receberam sucedâneo comparados aos que receberam leite $(3,10$ e 3,60, sucedâneo e leite, respectivamente), visto que consumiram a mesma quantidade de matéria seca, mas os do tratamento com sucedâneo ganharam mais peso.

\subsubsection{Idade ao início do consumo de silagem de milho}

Quando o animal atingia o consumo de $2,5 \mathrm{~kg} / \mathrm{dia}$ de concentrado, então passava a receber também silagem de milho como complemento, pois o concentrado era fixado nessa quantidade. Não houve efeito do processamento do milho nem de interação desse fator com o tipo de dieta líquida sobre a idade de início de consumo de silagem de milho. Entretanto os animais que receberam sucedâneo, começaram a consumir silagem mais tarde $(70,7$ dias; Tabela 7$)$ em relação aos animais que receberam o sucedâneo $(66,0$ dias; $\mathrm{P}<0,05$ ).

Observa-se através da Tabela 7 , que os animais que receberam sucedâneo também foram os que consumiram menos MS/dia, durante a fase da desmama até os 120 dias, indicando que também houve um baixo consumo de concentrado, mas de maneira crescente até atingir os $2,5 \mathrm{~kg}$, retardando o início do consumo de silagem de milho. 


\subsection{Desempenho dos 15 dias de idade ao final do experimento (120 dias)}

\subsubsection{Consumo de matéria seca total}

O consumo de matéria seca total corresponde ao consumo de matéria seca do leite ou sucedâneo, do concentrado e da silagem de milho. O tipo de dieta líquida e sua interação com o processamento de milho afetaram o consumo de matéria seca durante todo o período experimental $(P<0,05)$, entretanto não foi observado efeito do processamento do milho (Tabela 9).

O menor consumo diário de MS para o período total do experimento, observado nos animais que foram tratados com sucedâneo $(1,92 \mathrm{~kg} / \mathrm{dia}$; Tabela 9) comparado com os tratados com leite $(2,04 \mathrm{~kg} / \mathrm{dia})$ também foi observado durante a fase de aleitamento e após a desmama (Tabelas 5 e 7), elucidando novamente, o baixo consumo de MS proveniente do sucedâneo (378 vs. 566 g/dia, sucedâneo e leite, respectivamente). Este baixo desempenho durante 0 aleitamento não foi possível de ser recuperado com maior eficiência após a desmama.

O grupo dos animais que recebeu leite não sofreu efeito significativo do processamento do milho, já no grupo tratado com sucedâneo, o consumo médio de MS dos animais que consumiram o concentrado com milho moído fino $(1,70$ $\mathrm{kg} / \mathrm{dia}$ ) foi menor $(\mathrm{P}<0,05)$ que os demais (floculados). É interessante notar que os animais tratados com leite e que consumiram o concentrado com milho moído fino apresentaram, numericamente, um dos maiores consumos de matéria seca enquanto que os tratados com sucedâneo e o mesmo processamento apresentaram o menor consumo de MS (Tabela 8 ).

Observando-se apenas o consumo dos concentrados contendo milho floculado (Tabela 9), nota-se que, numericamente o maior consumo de MS/dia foi para o floculado $437 \mathrm{~g} / \mathrm{L}$, seguido do $283 \mathrm{~g} / \mathrm{L}$, e por $360 \mathrm{~g} / \mathrm{L}$, sendo contrastantes aos encontrados por Xiong et al. (1991), que utilizaram as mesmas densidades do sorgo floculado em novilhos confinados. Eles 
verificaram que os animais alimentados com sorgo de menor densidade (283 g/L), consumiram menos MS. Reinhardt et al. (1997), Theurer et al. (1999) e Swingle et al. (1999) também observaram que o consumo de MS diminuía com a diminuição da densidade do grão floculado em vacas leiteiras e novilhos confinados. Já Zinn (1990a) não encontrou diferença significativa $(P>0,05)$ entre o consumo de MS em novilhos em confinamento que consumiram milho floculado nas densidades 420,360 e $300 \mathrm{~g} / \mathrm{L}$. Segundo Swingle et al. (1993), em dietas para novillhos em confinamento, o consumo diminuiu linearmente em resposta à diminuição da densidade, sendo essa diminuição atribuída ao aumento de densidade energética em dietas quando o grão é floculado a densidades mais baixas. A diferença nas respostas entre o presente trabalho e os dos outros autores, poderia ser explicado pelo fato das dietas para novilhos apresentarem maiores quantidades do grão floculado (>70\%) nas formulações, do que o concentrado fornecido aos bezerros (51\%).

Plascentia \& Zinn (1996) forneceram milho floculado nas densidades 390,320 e $260 \mathrm{~g} / \mathrm{L}$ para vacas em lactação e não observaram diferenças no consumo de MS entre as densidades. No entanto, Moore et al. (1990) analisando os efeitos do grão de sorgo floculado a $270 \mathrm{~g} / \mathrm{L}$ e $400 \mathrm{~g} / \mathrm{L}$, observaram redução do consumo de MS para o floculado de menor densidade.

A Figura 2 apresenta o consumo de matéria seca total dos 15 dias ao final do experimento. 


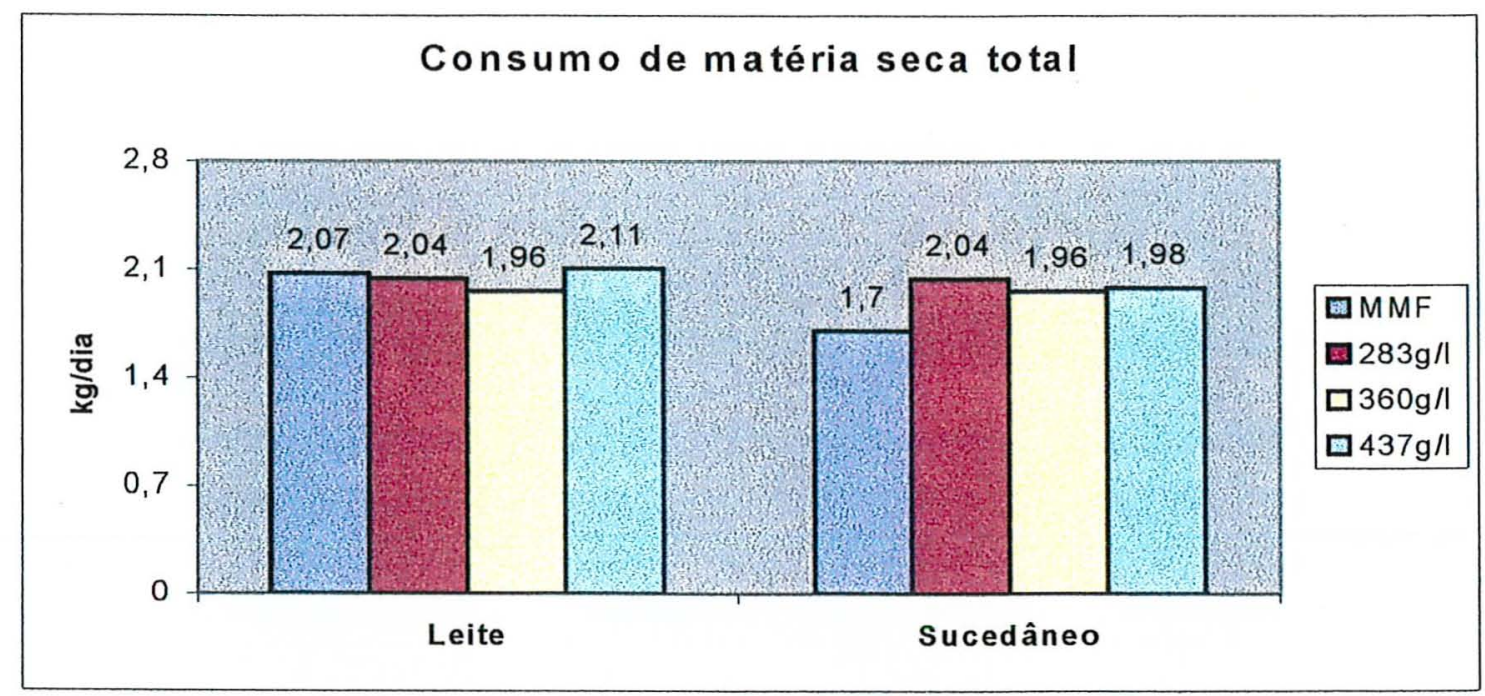

MMF = milho moído fino; $283 \mathrm{~g} / \mathrm{L}=$ floculado $283 \mathrm{~g} / \mathrm{L} ; 360 \mathrm{~g} / \mathrm{L}=$ floculado $360 \mathrm{~g} / \mathrm{L} ; 437 \mathrm{~g} / \mathrm{L}=$ floculado $437 \mathrm{~g} / \mathrm{L}$.

Figura 2. Consumo de matéria seca dos 15 dias ao final do experimento. 
Tabela 9. Efeitos do processamento do milho e tipo de dieta líquida sobre o desempenho dos(as) bezerros(as) dos 15 aos 120 dias de idade (dados corrigidos pela covariável peso aos 15 dias).

\begin{tabular}{|c|c|c|c|c|c|c|c|c|c|c|}
\hline \multirow[t]{2}{*}{ Parâmetro } & \multicolumn{2}{|c|}{ Dieta líquida } & \multicolumn{4}{|c|}{ Processamento ${ }^{1}$} & \multirow[b]{2}{*}{ Média } & \multirow[b]{2}{*}{$\mathrm{EPM}^{4}$} & \multicolumn{2}{|l|}{$\overline{P^{2}}$} \\
\hline & Leite & Suced. $^{3}$ & MMF & 283 & 360 & 437 & & & D. Liq. & Proc. \\
\hline$\overline{\mathrm{CMS}(\mathrm{kg} / \mathrm{dia})^{5}}$ & 2,04 & 1,92 & 1,89 & 2,04 & 1,96 & 2,06 & 1,98 & 0,038 & 0,0432 & $\overline{\text { NS }}$ \\
\hline Peso inicial ${ }^{6}$ & 42,5 & 41,8 & 42,9 & 41,7 & 42,5 & 41,5 & 42,2 & . & 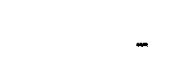 & . \\
\hline $\mathrm{GP}(\mathrm{kg} / \mathrm{dia})^{7}$ & 0,73 & 0,62 & 0,63 & 0,70 & 0,67 & 0,69 & 0,68 & 0,012 & 0,0001 & NS \\
\hline$C A^{8}$ & 2,76 & 3,17 & 2,98 & 2,94 & 2,96 & 2,97 & 2,97 & 0,051 & 0,0051 & NS \\
\hline PV $(k g)^{9}$ & 119,00 & 106,8 & 108,5 & 114,3 & 114,6 & 109,6 & 113,9 & 1,410 & 0,0001 & NS \\
\hline
\end{tabular}


Tabela 10. Interação entre processamento do milho e tipo de dieta líquida sobre o desempenho dos(as) bezerros(as) dos 15 aos 120 dias de idade (dados corrigidos pela covariável peso aos 15 dias).

\begin{tabular}{|c|c|c|c|c|c|c|c|c|c|c|c|c|c|c|}
\hline \multirow[t]{2}{*}{ Parâmetro } & \multicolumn{4}{|c|}{ Leite } & \multicolumn{4}{|c|}{ Sucedâneo } & \multirow[b]{2}{*}{$\mathrm{EPM}^{5}$} & \multirow[b]{2}{*}{$P X L^{6}$} & \multicolumn{2}{|c|}{$P(L)^{7}$} & \multicolumn{2}{|c|}{$P(S)^{8}$} \\
\hline & MMF $^{1}$ & $283^{2}$ & $360^{3}$ & $437^{4}$ & MMF & 283 & 360 & 437 & & & MxF & Floc & $\mathbf{M x F}$ & Floc \\
\hline CMS(kg/dia) $)^{9}$ & 2,07 & 2,04 & 1,96 & 2,11 & 1,70 & 2,04 & 1,96 & 2,00 & 0,029 & 0,0421 & NS & NS & 0,0129 & IV \\
\hline Peso inicial ${ }^{10}$ & 43,2 & 41,6 & 43,2 & 41,8 & 42,6 & 41,7 & 41,9 & 41,2 & - & - & - & - & - & - \\
\hline $\mathrm{GP}(\mathrm{kg} / \mathrm{dia})^{11}$ & 0,74 & 0,73 & 0,74 & 0,73 & 0,52 & 0,67 & 0,61 & 0,65 & 0,012 & 0,0301 & NS & NS & 0,0331 & NS \\
\hline $\mathrm{CA}^{12}$ & 2,77 & 2,78 & 2,64 & 2,84 & 3,21 & 3,11 & 3,28 & 3,09 & 0,051 & NS & NS & NS & NS & $N$ \\
\hline $\operatorname{PV}(\mathrm{kg})^{13}$ & 119,4 & 118,8 & 118,8 & 118,9 & 97,6 & 109,8 & 110,4 & 109,6 & 1,410 & 0,0404 & NS & NS & 0,0024 & $N$ \\
\hline
\end{tabular}

1 = milho moldo fino; 2 = floculado $283 \mathrm{~g} / \mathrm{l} ; 3=$ floculado $360 \mathrm{~g} / \mathrm{l} ; 4$ = floculado $437 \mathrm{~g} / \mathrm{l} ; 5$ = erro padrăo da média; 6 = probabilidade de interaçăo processamento $\mathrm{x}$ dieta liquida; $7=$ probabilidade de efeito do processamento do milho dentro de dieta com leite: $\mathrm{MxF}=$ contraste de milho moido $v \mathbf{~}$ floculados; Floc $=$ contrastes entre floculados; $8=$ probabilidade de efeito do processamento do milho dentro de dieta com sucedaneo; $9=$ consumo de MS total (concentrado+silagem de milho); $10=$ peso vivo aos 15 dias de vida (covariável); $11=$ ganho de peso médio diário; $12=$ conversão alimentar ( $\mathrm{kgCMS} / \mathrm{kgGP}$ ); $13=$ peso vivo aos 120 dias 


\subsubsection{Ganho de peso}

O fornecimento do milho processado não afetou o ganho de peso dos 15 aos 120 dias de vida, mas houve efeito da dieta líquida $(P<0,05)$. Em média, os animais que receberam sucedâneo ganharam $0,62 \mathrm{~kg} / \mathrm{dia}$ enquanto que aqueles que receberam leite ganharam $0,73 \mathrm{~kg} / \mathrm{dia}$ (Tabela 9). Os efeitos do fornecimento do milho processado e o tipo de dieta líquida tiveram interação significativa $(\mathrm{P}<0,05)$ sobre $\circ$ ganho de peso médio diário durante todo 0 período experimental. Os animais que receberam leite não tiveram diferenças significativas entre os concentrados para o ganho de peso diário (Tabela 10). Já no tratamento com sucedâneo, houve diferença entre o concentrado contendo milho moído fino e os floculados $(\mathrm{P}<0,05)$. O milho moído fino proporcionou menor ganho de peso $(0,52 \mathrm{~kg} / \mathrm{dia})$ ao ser comparado com os floculados. Do mesmo modo como já visto, os animais do mesmo tratamento foram os que tiveram o menor consumo de matéria seca oferecida.

Silva et al. (1987) verificaram que o ganho de peso médio não diferiu entre os tratamentos com leite e sucedâneo e os animais que receberam leite ganharam $0,54 \mathrm{~kg} /$ dia enquanto que os animais do sucedâneo ganharam 0,58 $\mathrm{kg} / \mathrm{dia}$ do nascimento aos 122 dias de vida. Além dessa resposta ter sido contrastante à encontrada no presente trabalho, pois os animais tratados com leite ganharam mais peso do que os do sucedâneo, verificou-se também que os ganhos de peso encontrados por esses autores estão abaixo dos encontrados neste estudo. Os resultados contrastantes podem ser devido a qualidade e quantidade de alimento seco que era fornecido aos animais. Respostas similares ao presente estudo foram encontradas por Matos et al. (1984) e Vasconcelos et al. (1998).

O ganho de peso médio diário dos animais tratados com leite $(0,73$ $\mathrm{kg} / \mathrm{dia}$ ) está acima do recomendado por Farias \& Ghelfi (1993) que é de 0,68 $\mathrm{kg} / \mathrm{dia}$ do nascimento aos 4 meses, como estratégia de crescimento de novilhas para a atingirem a parição aos 24 meses e pesando $550 \mathrm{~kg}$. O ganho de peso 
dos animais tratados com sucedâneo $(0,62 \mathrm{~kg} / \mathrm{dia})$ foi ligeiramente inferior ao proposto pelos mesmos autores.

Xiong et al. (1991) não encontraram diferenças no ganho de peso médio em novilhos confinados, consumindo dietas com sorgo floculado em densidades semelhantes as utilizadas no presente trabalho. Swingle et al. (1999) avaliando o efeito do sorgo floculado a 412, 360, 309 e $257 \mathrm{~g} / \mathrm{L}$, no desempenho de novilhos em confinamento, verificaram que o ganho de peso médio diário diminuía com a diminuição da densidade. Da mesma forma, Reinhardt et al. (1997) e Theurer et al. (1999) também encontraram resultados semelhantes a esses autores.

Shuh et al. (1970) não observaram diferenças no ganho de peso diário em bezerros que receberam grão de sorgo laminado ( $540 \mathrm{~g} / \mathrm{dia}$ ) e floculado (560 g/dia), cevada laminada (570 g/dia) e floculada (560 g/dia), mas os ganhos de pesos observados por esse autores foram menores aos encontrados neste trabalho. Shuh et al. (1971) também observaram menores ganhos de peso, comparados com os deste estudo ao utilizar sorgo floculado e sorgo processado por pressão.

A Figura 3 apresenta o ganho de peso médio diário dos 15 dias aos 120 dias de idade. 


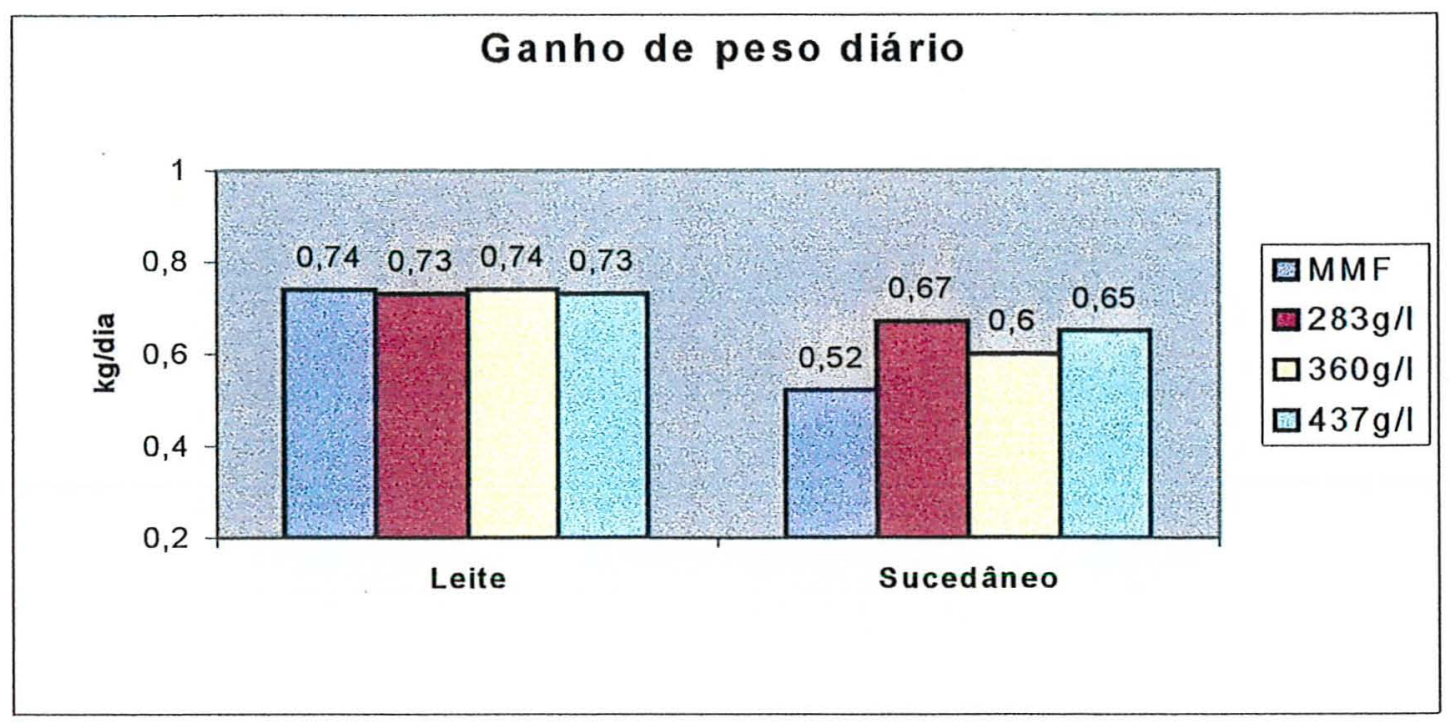

MMF = milho moído fino; $283 \mathrm{~g} / \mathrm{L}=$ floculado $283 \mathrm{~g} / \mathrm{L} ; 360 \mathrm{~g} / \mathrm{L}=$ floculado $360 \mathrm{~g} / \mathrm{L} ; 437 \mathrm{~g} / \mathrm{L}=$ floculado $437 \mathrm{~g} / \mathrm{L}$.

Figura 3. Ganho de peso médio diário dos 15 dias ao final do experimento.

\subsubsection{Conversão Alimentar}

O fornecimento do milho processado e sua interação com o tipo de dieta líquida não afetaram a conversão alimentar média total (durante toda a fase experimental), mas houve efeito significativo para o tipo de dieta líquida $(\mathrm{P}<0,05)$. Animais que receberam sucedâneo apresentaram conversão alimentar (3,17 $\mathrm{kg} \mathrm{MS} / \mathrm{kg}$ de ganho de peso) $14,5 \%$ maior que a do leite $(3,17$ $\mathrm{kg} \mathrm{MS/GP;} \mathrm{Tabela} \mathrm{9).} \mathrm{Essa} \mathrm{CA} \mathrm{foi} \mathrm{maior} \mathrm{do} \mathrm{que} \mathrm{as} \mathrm{encontradas} \mathrm{por}$ Vasconcelos et al. (1998), que obtiveram CA alimentar de 1,77 para animais tratados com leite e 2,46 para sucedâneo. Porém, os dados encontrados no presente experimento estão de acordo aos encontrados por Silva et al. (1987), apesar das dietas sólidas serem diferentes.

As CA encontradas por Shuh et al. (1970) para sorgo laminado $(2,58)$ e o sorgo floculado $(2,22)$ foram melhores do que as CA encontradas neste 
trabalho, com milho floculado. Da mesma forma, Shuh et al. (1971) obtiveram respostas semelhantes.

Zinn (1990a) também não encontrou diferenças na CA em novilhos confinados que receberam milho floculado nas densidades 420, 360 e $300 \mathrm{~g} / \mathrm{L}$. Ele verificou que diminuindo a densidade do grão floculado não melhorou o desempenho dos animais. Theurer et al. (1999) observaram que com a diminuição da densidade de floculação do sorgo de 386 para $257 \mathrm{~g} / \mathrm{L}$ diminuiu a CA em 4\%, mas não afetou o ganho de peso dos novilhos confinados. Respostas similares também foram observadas por Xiong et al. (1991), Reinhardt et al. (1997), Swingle et al. (1999) em que a diminuição da densidade não afetava a conversão alimentar, apesar de diminuir o consumo de MS e o ganho de peso médio diário em aproximadamente $5 \%$.

A Figura 4 apresenta a conversão alimentar dos 15 aos 120 dias de idade.

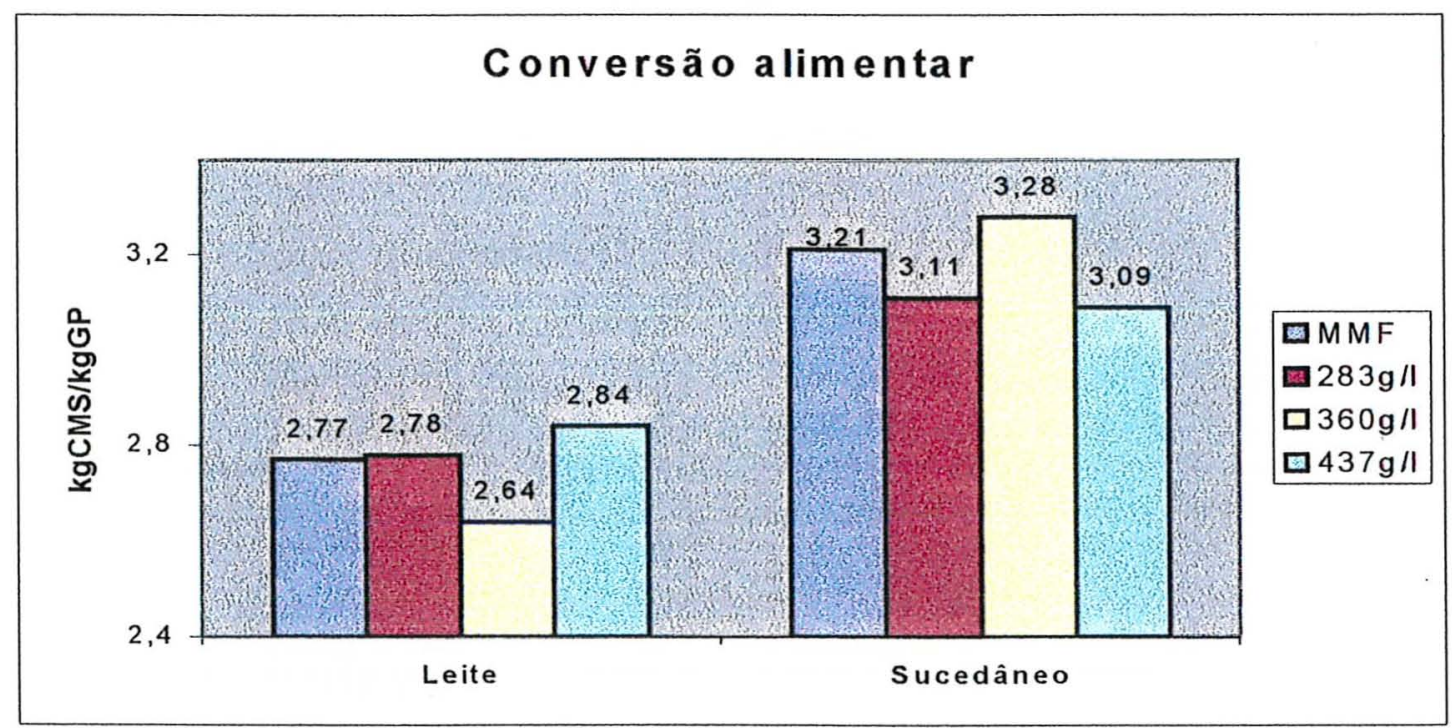

MMF = milho moído fino; $283 \mathrm{~g} / \mathrm{L}=$ floculado $283 \mathrm{~g} / \mathrm{L} ; 360 \mathrm{~g} / \mathrm{L}=$ floculado $360 \mathrm{~g} / \mathrm{L} ; 437 \mathrm{~g} / \mathrm{L}=$ floculado $437 \mathrm{~g} / \mathrm{L}$.

Figura 4. Conversão alimentar dos 15 dias ao final do experimento. 


\subsubsection{Peso vivo final (120 dias)}

O peso final aos 120 dias de vida foi afetado pelo tipo de dieta líquida e ocorreu uma interação entre dieta líquida e processamento do milho $(P<0,05$; Tabelas 9 e 10), mas o processamento do milho não afetou o peso. Em média, os animais que receberam sucedâneo apresentaram menor ganho de peso do que aqueles que receberam leite $(0,62$ vs. $0,73 \mathrm{~kg} / \mathrm{dia}$; Tabela 9$)$ durante todo $\circ$ período experimental, afetando desse modo o peso ao final do experimento $(106,8$ vs. $119,0 \mathrm{~kg})$. Deve-se levar em consideração que os animais do tratamento com sucedâneo também apresentaram menor peso à desmama (Tabela 5), de modo que esse menor desempenho não foi recuperado após a desmama, como já mencionado. Hopkins (1997) encontrou respostas semelhantes ao presente trabalho e verificou que bezerros aos 120 dias de vida apresentaram peso médio de $115 \mathrm{~kg}$.

Os animais tratados com sucedâneo e o concentrado com milho moido fino (Tabela 10), foram os que apresentaram o menor peso vivo final $(97,6 \mathrm{~kg})$. Esse fato deve ser reflexo do menor consumo de concentrado e ganho de peso durante todo o periodo experimental.

\subsection{Taxa de mortalidade e ocorrência de diarréia}

Durante toda a fase experimental não houve nenhuma ocorrência de morte entre os 96 bezerros(as) do experimento. Segundo Campos \& Liziere (1998), taxa de mortalidade considerada razoável deve ser de no máximo 5\%.

Todos os animais apresentaram diarréia entre o $7^{\circ}$ e $10^{\circ}$ dia de vida, fato esse que já vinha ocorrendo na fazenda mesmo antes do início do experimento. A causa de diarréia após várias análises laboratoriais não foi possivel de ser identificada. Mesmo com diarréia, não houve suspensão do fornecimento do leite. Logo no início da diarréia, os animais foram tratados com antibiótico oral (Profloxin®). 


\section{CONCLUSÕES}

O processamento do milho não afetou o desempenho dos animais.

A substituição do leite integral pelo sucedâneo prejudicou o desempenho dos animais, porém a conversão alimentar foi semelhante da desmama ao final do experimento.

Os animais que receberam sucedâneo e o concentrado com milho moído fino apresentaram a maior idade à desmama e menor peso vivo aos 120 dias em conseqüência do menor ganho de peso e consumo de matéria seca dos 15 aos 120 dias de vida. 


\section{REFERÊNCIAS BIBLIOGRÁFICAS}

ABDELGAIR, I.E.; MORRIL, J.L.; HIGGINS, J.J. Effect of roasting soybeans and corn on dairy calf performance. Journal of Dairy Science, v.76 (Suppl.1), p.378 (Abstr.), 1993)

ABDELGAIR, I.E.; MORRIL, J.L. Effect of processing sorghum grain on dairy calf performance. Journal of Dairy Science, v.78, p.2040-2046, 1995.

ABDELGAIR, I.E.; MORRIL, J.L.; HIGGINS, J.J. Effect of roasted soybeans and corn on performance and ruminal and blood metabolites of dairy calves. Journal of Dairy Science, v.79, p.465-475, 1996a.

ABDELGAIR, I.E.; MORRIL, J.L.; HIGGINS, J.J. Ruminal availabilities of protein and starch: effects on growth and ruminal and plasma metabolites of dairy calves. Journal of Dairy Science, v.79, p.283-290, 1996b.

ABRAHÃO, J.J.S. Aleitamento de terneiros leiteiros com leite integral ou com sucedâneo à base de soja. Porto Alegre, 1980. 100p. Dissertação (Mestrado) - Faculdade de Agronomia, Universidade Federal do Rio Grande do Sul. 
ALVES, P.A.M.; LIZIERE, R.S.; CAMPOS, O.F.C.; VIEIRA, M.I.; GALDINO, J. Teste de um sucedâneo e um probiótico comerciais para bezerros de rebanhos leiteiros. In: XXXIV Reunião anual da Sociedade Brasileira de Zootecnia, Juiz de Fora, MG, 1997. Anais, Juiz de Fora, SBZ, 1997, p.221223.

ANDERSON, K.L.; NAGARAJA, T.G.; MORRIL, J.L. Ruminal metabolic development in calves weaned conventionally or early. Journal of Dairy Science, v.70, p.1000-1005, 1987a.

ANDERSON, K.L.; NAGARAJA, T.G.; MORRIL, J.L., AVERY, T.B.; GALITZER, S.J.; BOYER, J.E. Ruminal microbial development in conventionally or early weaned calves. Journal of Animal Science, v.64, p.1215-1226, 1987b.

A.O.A.C. Association of Official Analytical Chemists. Official Methods of Analysis. 12. Ed., Washington, D.C., 1990.

BANYS, V.L.; PAIVA, P.C.A.; ALVARENGA, L.C.; FREITAS, P.M.R.; SILVEIRA, A.A. Uso de proteína texturizada de soja como ingrediente de sucedâneo para bezerros. In: XXXV Reunião Anual da Sociedade Brasileira de Zootecnia, Botucatu-SP, 1998. Anais. Botucatu: SBZ, 1998. p. 551-552.

BARMORE, J.A. New calf management practices enhance production efficiency. Feedstuffs, November 14, p.12-14, 1994.

BUSH, R.S. Preference among different grains expressed by young Holstein calves. Canadian Journal of Animal Science, v.69, p.1099-1103, 1989. 
BUSH, R.S.; NICHOLSON, J.W.G. The effects of weaning schedule, duration of milk feeding and fishmeal on calf performance. Canadian Journal of Animal Science, v.66, p.691-698, 1986.

CAMPOS, O.F.; HUBER, J.T.; MORRIL, J.L.; BROWNSON, R.K.; DAYTON, A.D.; HARRISSON, H.J.S.; WARNER, R.G. Spray dried fish solubles or soy protein concentrate in milk replacer formulation. Journal of Dairy Science, v. 65, p.97-104, 1982.

CAMPOS, O.F.; HUBER, J.T.; BERGEN, W.G. Partial substitution of milk protein with spray-dried fish soluble or soy protein concentrates in milk calf replacers. Journal of Dairy Science, v.65, p.1240-1246, 1986.

CAMPOS, O.F.; SILVA, A.G. Fontes alternativas de proteína no sucedâneo do leite para bezerros: revisão de literatura. Pesquisa Agropecuária Brasileira, v.21, p.1089-1099, 1986.

CAMPOS, O.F. Criação de bezerros até a desmama. In. PEIXOTO, A.M.; MOURA, J.C.; FARIA, V.P. (Ed.) Bovinocultura Leiteira - Fundamentos da Exploração Racional. Piracicaba: Fealq, 1993. p. 77-133.

CAMPOS, O.F.; LIZIERE, R.S. Estratégias para obtenção de fêmeas de reposição em rebanhos leiteiros. In: Anais do $10^{\circ}$ Simpósio sobre Produção Animal - Planejamento da Exploração Leiteira. Piracicaba: Fealq, 1998. 268p.

CARVALHO, E.M.R.; CARVALHO, S.R.; LEAL, S.M.; NASCIMENTO, F.L.; ARONOVICH, S. Desmama precoce de bezerros leiteiros, com restrição de leite e uso de concentrados e de pastagens de boa qualidade. Revista da Sociedade Brasileira de Zootecnia, v.12, p.535-550, 1983. 
CAUGHANT, I.; PETIT, H.V.; IVAN, M.; BARD, C.; SAVOIE, L.; TOULLEC, R.; THIROUIN, S.; YVON, M. In vivo and in vitro gastric emptying of milk replacers containing soybean protein. Journal of Dairy Science, v.77, p.533-540, 1994

CHEN, K.H.; HUBER, J.T.; THEURER, C.B.; SWINGLE, R.S.; SIMAS, J.; CHAN, S.C.; WU, Z.; SULLIVAN, J.L. Effect of steam flaking of corn and sorghum grains on performance of lactating cows. Journal of Dairy Science, v.77, p.1038-1043, 1994.

DANIELS, L.B.; WINNINGHAN, R.M.; HORNSBY, Q.R. Expansion-extrusion processed sorghum grain and soybeans in diets of dairy calves. Journal of Dairy Science, v.56, p.932-934, 1978.

DAVIS, G.H.; DRACKLEY, J.K. The development, nutrition, and management of the young calf. Ames: lowa State University Press, 1998. $339 p$.

DREAN, G.; HUEROU-LURON, I.; GESTIN, M.; ROME, V.; PLODARI, M.; BERNARD, C.; CHAYVIALLE, J.A.; GUILLOTEAU, P. Comparison of kinetics of pancreatic secretion and gut regulatory peptides in the plasma of preruminant calves fed milk or soybean protein. Journal of Dairy Science, v.81, p.1313-1321, 1998.

FARIA, V.P.; GHELFI, H. Manejo e alimentação de bovinos jovens em confinamento. In. PEIXOTO, A.M.; MOURA, J.C.; FARIA, V.P. (Ed.) Bovinocultura Leiteira - Fundamentos da Exploração Racional. Piracicaba: Fealq, 1993. p. 247-264. 
FISHER, L.J. An evaluation of milk replacers based on the growth rate, heath and blood chemistry of Holstein calves. Canadian Journal of Animal Science, v.56, p.587-594, 1976.

FUNABA, M.; KAGIYAMA, K.; IRIKI, T.; ABE, M. Changes in nitrogen balance with age in calves weaned at $5 \circ 6$ weeks of age. Journal of Animal Science, v.72, p.732-738, 1994.

GALYEAN, M.L.; WAGNER, D.G.; JOHNSON, R.R. Site and extent of starch digestion in steers fed processed corn rations. Journal of Animal Science, v.43, p.1088-1094, 1976.

GRAY, G.M. Starch digestion and absorption in nonruminants. Journal of Nutrition, v.122, p.172, 1992.

GREENWOOD, R.H.; MORRIL, J.L.; TITGEMEYER, E.C. Using dry feed intake as a percentage of initial body weight as a weaning criterion. Journal of Dairy Science, v.80, p.2542-2546, 1997.

HALE, W.H. Influence of processing on the utilization of grains (starch) by ruminants. Journal of Animal Science, v.37, p. 1075-1080, 1973.

HARMON, D.L. Nutritional regulation of postruminal digestive enzymes in ruminants. Journal of Dairy Science, v. 76, p. 2102-2115, 1993

HOPKINS, B.A. Effects of the method of calf starters delivery and effects of weaning age on starter intake and growth of Holstein calves fed milk once daily. Journal of Dairy Science, v.80, p.2200-2203, 1997. 
HUBER, J.T.; JACOBSON, N.L.; MCGILLIARD, A.D.; ALLEN, R.S. Utilization of carbohydrate introduced directly into omaso-abomasal area of the stomach of cattle of various age. Journal of Dairy Science, v.44, p.321-330, 1961.

HUBER, J.T.; NATRUJAN, S.; POLAN, C.E. Varying levels of starch in calf milk replacers. Journal of Dairy Science, v.51, p.1081-1085, 1968.

HUBER, J.T.; SILVA, A.G.; CAMPOS, O.F.; MATHIEU, C.M. Influence of feeding different amounts of milk on performance, health and absorption capability of baby calves. Journal of Dairy Science, v.67, p.2957-2963, 1984.

HUNTINGTON, G.B. Ruminant starch utilization progress has been extensive. Feedstuffs, June 6, p.16, 1994.

JASTER, E.H.; McCOY, G.C.; FERNANDO, R.L. Dietary fat in milk or milk replacers for dairy calves raised during winter. Journal of Dairy Science, v.73, p.1843, 1990.

JENKINS, K.J. Pepsin and pancreatin supplementation of calf milk replacer containing soy protein. Canadian Journal of Animal Science, v.61, p.469$476,1981$.

JOY, M.T.; DePETERS, E.J.; FADEL, J.G.; ZINN, R.A. Effects of corn processing on the site and extent of digestion in lactating cows. Journal of Dairy Science, v.80, p.2087-2097, 1997.

KEARL, L.C. Nutrient Requirements of Ruminants in developing countries. In International Feedstuffs Institute. Utah State University, Logan, Utah, 1982. 
KERTZ, A.F.; PREWITT, L.R.; EVERETT, J.P. An early weaning calf program: summarization and review. Journal of Dairy Science, v.62, p.1835-1843, 1979.

KOTARSKI, S.F.; WANHISHA, R.D.; THURN, K.K. Starch hidrolysis by the ruminal microflora. Journal of Nutrition, v.122, p.178-190, 1992.

LALLĖS, J.P. Nutritional and antinutritional aspects of soyabean and field pea proteins used in veal calf production: a review. Livestock Production Science, v.34, p.181-202, 1993.

LYFORD, S.J.; HUBER, J.T. Digestion, metabolism and nutrient needs in preruminant. In: $\mathrm{CHURCH}$, D.C. The ruminant animal digestive physiology and nutrition. New Jersey: Prentice Hall, 1988, p-401-420.

LIZIERE, R.S.; CAMPOS, O.F. Alimentação de bezerros. Informe Agropecuário, v.16, n.175, p.32-36, 1992.

LUCCl, C. Bovinos Leiteiros Jovens: nutrição, manejo e doenças. São Paulo: Nobel, 1989. 371p.

MAIGA, H.A.; SCHINGOETHE, J.D.; FENTON, C.L.; TUCKER, W.L.; CASPER, D.P. Response of calves to diets that varied in amounts of ruminally degradable carbohydrate and protein. Journal of Dairy Science, v.77, p.278-283, 1994.

MATOS, L.L.; CAMPOS, O.F.; PIRES, M.F.A.; LEITE, L.O. Comparação entre leite integral e diferentes sucedâneos do leite na alimentação de bezerros. Revista da Sociedade Brasileira de Zootecnia, v.13, n.4, p.447-455, 1984. 
MCALLISTER, T.A.; RODE, L.M.; MAJOR, D.J.; CHENG, K.J.; BUCHANANSMITH, J.G. Effect of ruminal microbial colonization on cereal grains digestion. Canadian Journal of Animal Science, v.70, p.571-579, 1990.

MIR, P.S.; BURTON, J,H.; BUCHANAN-SMITH, J.G. Nutritional performance of calves fed milk replacers containing processed soybean. Canadian Journal of Animal Science, v.71, p.97-106, 1991.

MOORE, J.A.; POORE, M.H.; ECK, T.P.; ARANA, M.J.; SWINGLE, R.S., HUBER, J.T. Effect of sorghum grain processing on the performance of lactating dairy cows (LDC). Journal of Dairy Science, v.73 (Suppl. 1), p.127 (Abstr.), 1990.

MOORE, J.A.; POORE, M.H.; ECK, T.P.; SWINGLE, R.S.; HUBER, J.T.; ARANA, M.J. Sorghum grain processing and buffer addition for early lactation cows. Journal of Dairy Science, v.75, p.3465-3472, 1992.

MORRIL, J.L.; STEWART, W.E.; McCORMICK, R.J. Pancreatic amylase secretion by the young calves. Journal of Dairy Science, v. 53, p.72, 1970.

MORRILL, J.L.; DAYTON, A.D.; BEHNKE, K.C. Increasing consumption of dry feed by young calves. Journal of Dairy Science, v.64, p.2216-2219, 1981.

MORRIL, J.L. Early rumen development and how it relates to subsequent feedlot performance of Holstein calves: strategies for optimum health and growth. In: Southwest Nutrition and Management Conference, Phoenix, Arizona, 1993. Conference Proceedings, University of Arizona, Arizona, 1992. 
NITSAN, Z.R.; VOLVANI, R.; GORDINI, S.; HASDAI, A. Growth and nutrient utilization by calves fed milk replacers containing milk or soybean protein concentrate heated to various degrees. Journal of Dairy Science, v.54, p.1294-1299, 1971.

NITSAN, Z.R.; VOLVANI, R.; GORDINI, S.; HASDAI, A. Soybean protein substitute for milk protein in milk replacers for suckling calves. Journal of Dairy Science, v.55, p.811-821, 1972.

NOCEK, J.E.; HEALD, C.W.; POLAN, C.E. Influence of ration physical form and nitrogen availability on ruminal morphology of growing bull calves. Journal of Dairy Science, v.67, p.334-343, 1984.

NOCEK, J.E. \& TAMMINGA, S. Site of digestion of starch in the gastrointestinal tract of dairy cows and its effect on milk and composition. Journal of Dairy Science, v.74, p.3598-3629, 1991.

OLIVARES-REYNA, L.; HERRERA-SALDAÑA, R.; GAMA, R.B.; MUÑOZ, S.G. The effect of different protein and starch sources in starters for young calves. Journal of Dairy Science, v.75 (Suppl.1), p.269, 1992 (Abstr.).

OLIVEIRA, J.S.; HUBER, J.T.; BEM-GHEDALIA D.; SWINGLE R.S.; THEURER, C.B.; PESSARAKLI, M. Influence of sorghum grain processing on performance of lactating cows. Journal of Dairy Science, v.76, p. 575-583, 1993.

ORSKOV, E.R. Starch digestion and utilization in ruminants. Journal of Animal Science, v.63, p.1624-1633, 1986. 
OWENS, F.N.; ZINN, R.A.; KIM, Y.K. Limits to starch digestion in the ruminant small intestine. Journal of Animal Science, v.63, p.1634-1648, 1986.

OWENS, F.N.; SECRIST, D.S.; HILL, W.J.; GILL, D.R. The effect of grain source and grain processing on performance of feedlot cattle: A review. Journal of Animal Science, v.75, p.868-879, 1997.

PLASCENCIA, A.; ZINN, R.A. Influence of flake density on the feeding value of steam-processed corn in diets for lactating cows. Journal of Animal Science, v.74, p.310-316, 1996.

POORE, M.H.; ECK, T.P.; SWUINGLE, R.S.; THEURER, C.B. Total starch and relative starch availability of feed grains. ABSTR. $35,20^{\text {th }}$ Biennial Conference on Rumen Function, Chicago, 1989.

REINHARDT, C.D.; BRANDT, R.T.; BEHNKE, K.C.; FREEMAN, A.S.; ECK, T.P. Effect of steam flaked sorghum grain density on performance, mill production rate, and subacute acidosis in feedlot steers. Journal of Animal Science, v.75, p.2852-2857, 1997.

ROONEY, L.W.; PFLUGFELDER, R.L. Factors affecting starch digestibility with special emphasis on sorghum and corn. Journal of Animal Science, v.63, p.1607-1623, 1986.

SAS. Users Guide: Statistics, Version 5 edition, 1991. SAS Inst., Inc., Cary, NC.

SHUH, J.D.; LIMA, J.O.A.; HALE, W.H.; THEURER, B. Steam-processed flaked grains versus steam-rolled grains for dairy calves. Journal of Dairy Science, v.53, p.475-479, 1970. 
SHUH, J.D.; HALE, W.H.; THEURER, B. Pressure cooking versus steam processing and flaking sorghum grain for dairy calves. Journal of Dairy Science, v.54, p.401-404, 1971.

SILVA, M.M.L.; VIEIRA, P.F.; TOSI, H; FAVORETTO,V.; KRONKA, S.N. Utilização de substituto do leite integral no aleitamento de bezerros de raças leiteiras em sistema de desaleitamento precoce. Revista da Sociedade Brasileira de Zootecnia, v.16, p.215-221,1987.

SILVA, A.G.; HUBER, J.T.; DeGREGORIO, R.M. Influence of substituting two types of soybean protein for milk on gain and utilization of milk replacers in calves. Journal of Dairy Science, v. 69, p.172-180, 1986.

SIMAS, J.M. Processamento de grãos para rações de vacas leiteiras. In: $9^{\circ}$ SIMPÓSIO SOBRE PRODUÇÃO ANIMAL, Piracicaba, 1997. Anais. P.7-32. Piracicaba: FEALQ, 1997.

STEWART, G.D.; SCHINGOETHE, D.J. Evaluation of high starch and high fat rations for dairy calves. Journal of Dairy Science, v.67, p.598-605, 1984.

SWINGLE, R. S. Impact of sorghum grain flake density on feedlot performance. In: Southwest Nutrition and Management Conference, Scottsdale, AZ, 1992. Conference Proceedings, Scottsdale, AZ, University of Arizona, 1992, p.55-63.

SWINGLE, R.S.; THEURER, B.; URIAS, A. Sorghum grain flake density and source of roughage in feedlot diets. In: Southwest Nutrition and Management Conference, Phoenix, AZ, 1993. Conference Proceedings, Phoenix, AZ, 1993, p.38-47. 
SWINGLE, R.S.; ECK, T.P.; THEURER, C.B.; De la LLATA, M.; POORE, M.H.; MOORE, J.A. Flake density of steam-processed sorghum grain alters performance and sites of digestible by growing-finishing steers. Journal of Animal Science, v.77, p.1055-1065, 1999.

TERNOUTH, J.H.; ROY, J.H.B.; THOMPSON, S.Y.; TOOTHILL, J.; GILLIES, C.M.; EDWARDS-WEBB, J.D. Concurrent studies of the flow of digesta in the duodenum and of exocrine pancreatic secretion of calves: 3 . Further studied on the addition of fat to skim milk and the use of non-milk proteins in milk substitute diets. British Journal of Nutrition, v.33, p.181-196, 1975,

THEURER, C.B. Grain processing effects on starch utilization by ruminants. Journal of Animal Science, v.63, p.1649-1662, 1986.

THEURER, C.B.; HUBER, J.T.; CHEN, K.H.; SWINGLE, R.S. Update on grain processing research in lactating cows. In: Southwest Nutrition and Management Conference, Phoenix, AZ, 1993. Conference Proceedings, Phoenix, AZ, University of Arizona, 1993, p.70-77

THEURER, C.B.; LOZANO, O.; ALIO, A. Ruminal vs. Intestinal starch digestion affects nutrient use and efficiency of gain in feedlot cattle. In: Southwest Nutrition and Management Conference, Phoenix, AZ, 1996a. Conference Proceedings, Phoenix, AZ, University of Arizona, 1996, p.97-108.

THEURER, C.B.; HUBER, J.T.; DELGADO-ELOURDUY, A. Steam flaking improves starch utilization and milk production parameters. In: Cornell Nutrition Conference, 1996b. Conference Proceedings. 1996, p121-130. 
THEURER, C.B.; SWINGLE, R.S.; WANDERLEY, R.C.; KATTNING, R.M.; URIAS, A; GHENNIWA, G. Sorghum grain flake density and source of roughage in feedlot cattle diets. Journal of Animal Science, v.77, p.10661073, 1999.

VAN SOEST, P.J.; ROBERTSON, P.J.; LEWIS, B.A. Methods for dietary fiber, neutral detergent fiber, and non-starch polysaccharides in relation to animal nutrition. Journal of Dairy Science, v.74, p. 3583-3596, 1991.

VAN SOEST, P.J. Nutrition ecology of the ruminants. Corvallis, Oregon: O \& Books, 1994. 476p.

VASCONCELOS, A.M.; FAÇANHA, D.A.E.; OLIVO, C.J.; CARVALHO, N.M. Utilização de substituto lácteo no desempenho de bezerros da raça holandesa. In: XXXV Reunião Anual da Sociedade Brasileira de Zootecnia, Botucatu-SP, 1998. Anais. Botucatu: SBZ, 1998. p.68-70.

WALDERN, D.R.; FISHER, L.J. Effect of steam processed barley, source of protein on fat intake and utilization of starter rations by dairy calves. Journal of Dairy Science, v.61, p.221-228, 1978.

WINTER, K.A. Comparative performance and digestibility in dairy calves weaned at three, five, and seven weeks of age. Canadian Journal of Animal Science, v.65, p.445-450, 1985.

YU, P.; HUBER, J.T.; SADIK, M.; SIMAS, J.; SANTOS, F.; AQUINO, J.; MENA, H.; SANTOS, J. Effect of corn processing on lactation performance of dairy cows. Journal of Dairy Science, v.78 (Suppl. 1), p.210 (Abstr.), 1995. 
YU, P.; HUBER, J.T.; SANTOS, F.A.P; SIMAS, J.M.; THEURER, C.B.; Effects of ground steam flaked, and steam rolled corn grains on performance of lactating cows. Journal of Dairy Science, v.81, p.777-783, 1998.

XIONG, Y.; BARTLE, S.J.; PRESTON, R.L. Density of steam-flaked sorghum grain, roughage level, and feeding regimen for feedlot steers. Journal of Animal Science, v.69, p.1707-1718, 1991.

ZINN, R.A. Influence of flake density on the comparative feeding value of steam-flaked corn for feedlot cattle. Journal of Animal Science, v.68, p.767-775, 1990a.

ZINN, R.A. Influence of steaming time on site of digestion of flaked corn in steers. Journal of Animal Science, v.68, p.776-781, 1990b.

ZINN, R.A. Comparative feeding value of steam-flaked corn and sorghum in finishing diets supplemented with or without sodium bicarbonate. Journal of Animal Science, v.69, p.905-916, 1991.

ZINN, R.A.; ADAM, C.F.; TAMAYO, M.S. Interaction of feed intake level on comparative ruminal and total tract digestion of dry-rolled and steam-flaked corn. Journal of Animal Science, v.73, p,1239-1245, 1995. 